How to cite this article:

Mohamed Redzwan, H. F., Bahari, K. A., Sarudin,A., \& Osman, Z. (2020). Strategi pengukuran upaya berbahasa menerusi kesantunan berbahasa sebagai indikator profesionalisme guru pelatih berasaskan skala morfofonetik, sosiolinguistik dan sosiopragmatik. Malaysian Journal of Learning \& Instruction, 17(1), 213-254. https://doi.org/10.32890/mjli2020.17.1.9

\title{
STRATEGI PENGUKURAN UPAYA BERBAHASA MENERUSI KESANTUNAN BERBAHASA SEBAGAI INDIKATOR PROFESIONALISME GURU PELATIH BERASASKAN SKALA MORFOFONETIK, SOSIOLINGUISTIK DAN SOSIOPRAGMATIK \\ (LINGUISTIC POLITENESS AS AN INDICATOR OF TRAINEE TEACHER PROFESSIONALISM: A LANGUAGE ABILTY MEASUREMENT STRATEGY BASED ON MORPHOPHONETIC, SOCIOLINGUISTIC AND SOCIOPRAGMATIC SCALES)
}

\author{
${ }^{1}$ Husna Faredza Mohamed Redzwan, ${ }^{2}$ Khairul Azam Bahari, \\ ${ }^{3}$ Anida Sarudin \& ${ }^{4}$ Zulkifli Osman \\ ${ }^{1-4}$ Jabatan Bahasa dan Kesusasteraan Melayu \\ Fakulti Bahasa dan Komunikasi, \\ Universiti Pendidikan Sultan Idris, Malaysia. \\ ${ }^{I}$ Corresponding author: husna.faredza@fbk.upsi.edu.my
}

Received: 14/11/2018 Revised: 31/12/2019 Accepted:1/1/2020 Publish: 31/1/2020

\section{ABSTRAK}

Tujuan - Kajian ini bertujuan untuk mengenal pasti upaya berbahasa menerusi penggunaan Bahasa Melayu Tinggi dan Berbudaya(BMTB) dalam kalangan guru pelatih sebagai ciri kesantunan yang dapat diukur menerusi Indikator Profesionalisme Guru Pelatih berdasarkan skala morfofonetik, sosiolinguistik dan sosiopragmatik.

Metodologi- Sembilan orang guru pelatih Bahasa Melayu daripada lima buah sekolah menengah terpilih di negeri Perak dijadikan responden. Kajian ini menggunakan pendekatan kualitatif yang 
memberikan kefahaman mendalam berkaitan dengan upaya BMTB dalam kalangan guru pelatih berasaskan senarai semak pencerapan pengajaran dan pemudahcaraan $(\mathrm{PdPc})$ yang dibina berpandukan penentuan skala morfofonetik; skala sosiolinguistik; dan skala sosiopragmatik mengikut kerangka konseptual Brown dan Levinson (1987). Pencerapan dilaksanakan terhadap sembilan orang guru pelatih dengan menganalisis rakaman sesi PdPc mereka yang berdurasi 540 minit dan telah ditranskripsikan.

Dapatan - Kajian ini menunjukkan bahawa masih terdapat ketidakpatuhan aspek morfofonetik terutamanya dalam mengartikulasikan perkataan-perkataan tertentudalambahasaMelayu dengan menggunakan sebutan baku dalam kalangan guru pelatih. Selain itu, ketidakpatuhan mereka terhadap peraturan sosiolinguistik juga dikesan, iaitu masih terdapat penggunaan bahasa yang kurang rapi kerana mengandungi percampuran kod. Ketidakpatuhan aspek morfofonetik dan sosiolinguistik ini perlu ditangani dengan baik agar upaya berbahasa dan tahap profesionalisme guru pelatih dapat ditingkatkan. Dari aspek sosiopragmatik pula, kesemua 15 substrategi kesantunan berbahasa di bawah Strategi Kesantunan Positif Brown dan Levinson (1987) didapati telah diamalkan oleh guru pelatih yang menunjukkan bahawa mereka memiliki upaya berbahasa yang positif dan memenuhi indikator profesionalisme sebagai bakal pendidik.

Signifikan - Kajian ini menyumbang kepada saranan membina indikator profesionalisme guru pelatih UPSI khususnya dan bakal pendidik umumnya dalam perspektif upaya BMTB bagi mengukur amalan kesantunan berbahasa, khususnya dalam bidang Bahasa Melayu semasa mereka menjalani latihan mengajar.

Kata Kunci-Upaya berbahasa, Bahasa Melayu Tinggidan Berbudaya (BMTB), Kesantunan Berbahasa, Indikator Profesionalisme Guru Pelatih, Morfofonetik, Sosiolinguistik, Sosiopragmatik.

\section{ABSTRACT}

Purpose - The aim of this study was to identify Malaysian trainee teachers' language ability through their use of high and cultured Malay language (HCML) as a politeness feature, as measured by 
morphophonetic, sociolinguistic and sociopragmatic scales in a Trainee Teacher Professionalism Indicator.

Methodology - Respondents were nine Malay language trainee teachers from five selected secondary schools in the state of Perak. A qualitative approach was used to gain in-depth understanding of their HCML ability. A teaching observation and facilitation checklist incorporating morphophonetic, sociolinguistic and sociopragmatic scales was developed based on Brown and Levinson's (1987) conceptual framework. Data was collected during classroom observations of the nine trainee teachers. Recordings of these sessions totalling 540 minutes were transcribed and analysed.

Findings - The study found some disregard for morphophonetic aspects of language use, especially in articulating particular words in standard Malay pronunciation. There was also evidence of inattention to sociolinguistic rules, i.e., looseness due to code mixing. These non-adherence issues should be addressed in an appropriate manner so that both the language ability and level of professionalism of trainee teachers can be enhanced. In the sociopragmatic aspect, however, all 15 linguistic politeness sub-strategies of Brown and Levinson's Positive Politeness Strategy (1987) were found to be practiced, indicating that the teacher trainees' language ability was positive, and fulfilled the professionalism indicator.

Significance - This study contributes towards the development of a teacher professionalism indicator for trainee teachers in the researchers' own institution and elsewhere from the perspective of HCML ability, that may be used to evaluate linguistic politeness during teaching practice, especially among Malay language trainee teachers.

Keywords - Language ability, high and cultured Malay language, linguistic politeness, trainee teachers' professionalism indicator, morphophonetic, sociolinguistic, sociopragmatic.

\section{PENGENALAN}

Sebagai warganegara Malaysia, penguasaan Bahasa Melayu Tinggi Dan Berbudaya (BMTB) perlu diberi perhatian utama kerana BMTB penting dalam mengajarkan Bahasa Melayu yang berupaya 
sebagai penggerak budaya tinggi (Karim, 1986; Nordin, Ariffin, Jamaluddin, Bahari, Mohamed Redzwan \& Yusof, 2014; Hassan, 2016; \& Yatim, 2017). BMTB dalam kajian ini dapat dikaitkan dengan penutur berpendidikan, majlis rasmi, bahasa terkawal dan rapi. Dari segi falsafahnya, BMT merupakan wahana budaya tinggi bagi menyalurkan ilmu pengetahuan, menjana idea, menyimpan himpunan budaya bangsa. BMT dari kategori neka bahasa terkawal dengan mengambil kira segala aspek bahasa: sebutan yang betul, intonasi yang betul, pilihan perkataan yang sesuai, tatabahasa yang rapi, penggunaan peribahasa yang sesuai dan kreatif, dan dapat menunjukkan budaya orang terpelajar dan berbudaya tinggi. Penggunaan sepenuhnya dikawal rapi(Hassan, 2016). Jelasnya, BMT merupakan neka formal, manakala Bahasa Melayu Rendah (BMR) merupakan neka mesra. Neka formal merujuk kepada bahasa yang digunakan secara teratur, lengkap dan mengandungi segala strategi pertuturan bagi memberi gambaran bahasa yang beradat, penuh rasa hormat dalam konteks formal. Bahasa formal mementingkan penggunaan kata yang sesuai mengikut konteks, kata-kata yang tersusun rapi, kata ganti nama yang sesuai, nahu yang tepat dan intonasi yang berpadanan (Hassan, 2016). Jelasnya, Bahasa Melayu sebagai bahasa kebangsaan, bahasa rasmi, bahasa negara dan bahasa warganegara perlu dimartabatkan dan diutamakan penggunaannya dalam konteks rasmi. Dalam masa yang sama, bahasa selain bahasa Melayu, dialek dan bahasa sukuan tidak dihalang penggunaannya dalam konteks tidak rasmi. Sebagai pengguna bahasa dan penutur natif bahasa Melayu khususnya Bahasa Melayu Tinggi dan Berbudaya (BMTB) mereka perlu bijak memilih bahasa yang wajar digunakan mengikut konteks dan keadaan. Dalam konteks kajian ini, pengguna bahasa dalam kalangan guru pelatih dan pelajar di sekolah perlu menggunakan BMTB khususnya kesantunan berbahasa dalam konteks rasmi, iaitu dalam bilik darjah.

Dalam konteks pengajaran bahasa, amalan pengajaran memainkan peranan penting dalam memastikan penguasaan bahasa dan kecekapan berbahasa dalam kalangan pelajar-pelajar (Idris, Sarudin dan Md. Idris (2013). Selain aspek nahu, bahasa perlu dipelajari dan dihayati dari sudut nilai dan maknanya. Bahasa yang kita tuturkan dan tuliskan, hendaklah betul dan rapi tatabahasanya, sebutannya, ejaannya, dan kosa katanya. Bahasa kita juga mesti berbudi bahasa bagi melincirkan iklim komunikasi (Hassan, 2012). Dalam erti kata lain, dikotomi antara penekanan pendidikan bahasa terhadap 
matlamat yang bersifat linguistik dengan matlamat yang bersifat pragmatis ini perlu dipadukan untuk memperoleh penguasaan bahasa yang seimbang antara kemahiran linguistik dengan kemahiran komunikatif. Kemahiran yang hanya menekankan kemahiran linguistik menyebabkan bahasa kehilangan fungsi sosialnya. Kemahiran yang hanya menekankan kemahiran komunikatif pula menyebabkan kehilangan piawai bahasa untuk dijadikan asas dalam pendidikan bahasa dan juga dalam komunikasi luas proses pengembangan kebudayaan dan tamadun bangsa (Sariyan, 2014). Ini menunjukkan bahawa bukan sekadar penyerapan ilmu secara teoritikal seperti kemahiran linguistik sahaja yang perlu dipentingkan, malah penyerapan nilai melalui pengajaran guru secara praktikal seperti kemahiran komunikatif guru dalam menyampaikan ilmu yang sarat nilai (value-laden) perlu disepadukan juga.

Dalam kajian ini, aspek upaya berbahasa menerusi kesantunan berbahasa yang diberikan tumpuan merupakan kualiti guru pelatih yang perlu dimiliki oleh setiap guru pelatih kerana kualiti ini merupakan indikator profesionalisme guru pelatih berimpak tinggi. Indikator profesionalisme guru pelatih yang diteliti terdiri daripada i) pematuhan aspek morfofonetik, iaitu sebutan perkataan dalam bahasa Melayu; ii) pematuhan aspek sosiolinguistik, iaitu upaya guru dalam menggunakan bahasa Melayu tinggi yang sesuai yang tidak mengandungi percampuran kod dan pengguna Bahasa Melayu Rendah; iii) pematuhan aspek sosiopragmatik yang meliputi strategi kesantunan berbahasa, iaitu Strategi Kesantunan Positif (Rujuk Rajah 1).

Chiew, C. M., Dali, Dali, M. H. \& Lim, C. S. (2016), juga berpandangan kualiti guru berhubung rapat dengan pembangunan profesional guru. Secara umumnya, profesionalisme merupakan struktur multidimensi yang merangkumi tingkah laku bekerja dan sikap yang mempamerkan standard tertinggi seseorang dalam meningkatkan kualiti perkhidmatan (Boyt, Lusch \& Naylor, 2001). Guru sebagai penyerlah profesion yang dapat mampu mengorganisasikan pendidikan terbaik kepada murid (Osman, Sarudin, Janan dan Omar, 2019; Osman, Sarudin, Abdul dan Ayob, 2019).

Dalam konteks pendidikan, profesionalisme guru diinterpretasikan sebagai sejauh mana guru mengatasi kesukaran dan sejauh mana mereka berupaya menggunakan kemahiran dan pengalaman 
dalam kerjaya mereka sebagai guru (Baggini, 2005). Selain itu, profesionalisme guru hendaklah berfokuskan kepada kelayakan profesional sebagai guru seperti cekap dalam pekerjaannya, memenuhi standard tertinggi, dan mencapai kecemerlangan (Demirkasımoğlu, 2010). Menurut Demirkasımoğlu (2010) lagi, profesionalisme guru juga diinterpretasikan sebagai profesional dalam bidang, sesuai dengan dimensi sosiologikal, ideologikal dan pendidikan dalam mencapai standard tertinggi yang berasaskan pembentukan, pengetahuan, kemahiran dan nilai profesional itu sendiri.

Cormin (1965), Havighurst \& Levine (1979), Howson et al. (1976) dalam Sariyan (2014) menegaskan bahawa kerjaya pendidik dikategorikan sebagai kerjaya yang profesional. Selain kemahiran dan ilmu linguistik yang tinggi (Mahmood, 2002); guru Bahasa Melayu yang profesional seharusnya berilmu dalam bidangnya serta mampu menerapkan strategi berfikir aras tinggi dalam PdPc (Sarudin, Mohamed Redzwan, Ayob \& Ramli, 2018). Selain itu, upaya berbahasa Melayu tinggi dan berbudaya dari sudut morfofonetik dan sosiolinguistik juga dipentingkan (Mohamed Redzwan, Sarudin \& Bahari, 2018a; 2018b). Dalam kertas kerja ini pula, profesionalisme guru pelatih sewajarnya perlu ditonjolkan melalui kemahiran sosial aras tinggi, iaitu dalam mengamalkan kesantunan berbahasa juga.

Mahmood (2002) mengatakan bahawa bahasa Melayu tidak dapat dimartabatkan jika guru-guru yang mengajar mata pelajaran tersebut tidak menggunakan bahasa Melayu dengan betul. Andainya seseorang guru itu tidak mempunyai kemahiran berkomunikasi, bererti guru itu tidak akan berjaya menyampaikan pengajarannya dengan berkesan yang seterusnya tidak mencapai matlamat melahirkan pendidikan yang bermutu (Mahmood, 2002). Jelasnya, keseimbangan dan kesepaduan kemahiran linguistik dan kemahiran komunikatif dalam kalangan guru pelatih sangat penting dan perlu ditangani dengan bijak.

Dalam kajian ini, kesantunan berbahasa sebagai indikator profesionalisme guru pelatih atau bakal pendidik relevan dan harus diberi penekanan, dititikberatkan dan ditingkatkan serta diteruskan amalannya dalam kalangan guru pelatih sebagai persediaan menjadi guru terlatih kelak. Hal ini demikian kerana guru merupakan agen dan model santun berbahasa yang berupaya menjadi contoh 
kepada pelajar khususnya dalam sesi PdPc di sekolah untuk turut menggunakan BMTB dengan menitikberatkan amalan kesantunan berbahasa. Dalam kupasan yang lebih telus, strategi kesopanan amat penting diterapkan dalam pengajaran dan pembelajaran bagi mewujudkan hubungan komunikasi yang lebih harmoni antara guru dan pelajar dan secara tidak langsung menjadi medium motivasi yang intrinsik dalam menggalakkan proses pembelajaran.

\section{PERNYATAAN MASALAH}

Dalam konteks pengamalan pendidikan Bahasa Melayu di universiti umumnya, sejauh mana teori bahasa yang pernah dipelajari semasa pengajian di universiti sebelum menjalani latihan mengajar diamalkan atau dipraktikkan dalam pengajaran guru pelatih semasa mengajarkan Bahasa Melayu dalam sesi Latihan mengajar? Menurut Arshad (2012) ramai guru masih menganggap teori tidak ada kaitannya dengan amalan. Sebagai contoh, dalam satu kajian tentang penerapan nilai pengajaran Bahasa Melayu mendapati bahawa para guru tidak menggunakan sebarang landasan atau pegangan yang tertentu dalam pelaksanaan pengajaran mereka dalam pengajaran Bahasa Melayu (Arshad, 2012). Persoalannya, adakah kursus Bahasa Melayu yang dipelajari secara teoretikal seperti Kursus Fonetik dan Fonologi Bahasa Melayu, Morfologi Bahasa Melayu, Sintaksis Bahasa Melayu, Semantik dan Pragmatik Bahasa Melayu dan Sosiolinguistik Melayu dapat diaplikasikan dan dizahirkan secara praktikal semasa menjalani latihan mengajar?

Jelasnya, keseimbangan dan kesepaduan kemahiran linguistik dan kemahiran komunikatif dalam kalangan guru pelatih juga perlu ditangani dengan bijak. Mahmood (2002) menyatakan bahawa bahasa Melayu tidak dapat dimartabatkan jika guru-guru yang mengajar mata pelajaran tersebut tidak menggunakan bahasa Melayu dengan betul. Beliau menambah melalui kajiannya menunjukkan bahawa masih ramai guru yang menggunakan dialek setempat semasa mengajar mata pelajaran Bahasa Melayu dan tidak menggunakan bahasa baku. Dalam erti kata lain, penggunaan BMTB kurang dipraktikkan sebagai amalan pengajaran. Selain pengaruh dialek, didapati bahawa kekacauan bahasa juga berlaku ditambah dengan pengaruh bahasa slanga dalam kalangan murid. Slanga cepat tumbuh dan cepat pupus selari dengan peredaran masa. Sungguhpun begitu 
slanga tetap wujud, berleluasa dan memberi cabaran dalam usaha memartabatkan BMTB.

Dalam usaha mencapai pendidikan yang bermutu, komunikasi yang berkesan memainkan peranan yang amat penting. Komunikasi yang berkesan diperlukan dalam setiap episod PdPc. Oleh sebab itu, setiap individu yang terlibat dalam proses pengajaran, iaitu guru, perlu memahami, menghayati dan memahirkan diri dalam berkomunikasi. Andainya seseorang guru itu tidak mempunyai kemahiran dalam berkomunikasi, bererti guru itu tidak akan berjaya menyampaikan pengajarannya dengan berkesan yang seterusnya tidak mencapai matlamat melahirkan pendidikan yang bermutu (Mahmood, 2002).

Oleh yang demikian, sewajarnya guru pelatih yang berwibawa dan berupaya berkomunikasi dan dalam konteks kajian ini berupaya dalam berbahasa Melayu tinggi dan berbudaya mampu menjadi model dan seterusnya agen penutur BMTB. Menurut Hassan (2012) anak-anak mempelajari bahasa yang baik itu daripada bahasa yang mereka baca, dan bahasa yang mereka dengar. Oleh sebab itu, guru perlu menggunakan gaya komunikasi yang baik dan menyerlahkan elemen tatabahasa dan tatasosialnya.

Selain permasalahan dalam mencapai keseimbangan dalam kemahiran linguistik dan kemahiran komunikatif yang mengandungi elemen sosiolinguistik dan sosiopragmatiknya, isu berkaitan latihan mengajar sehingga kini masih dibincangkan dan dibahaskan. Hal ini demikian kerana latihan mengajar merupakan salah satu komponen utama dalam Program Latihan Keguruan yang menuntut guru pelatih mempamerkan profesionalisme mereka semasa sesi latihan mengajar berlangsung. Menurut Lim, K. C., Mahat, N. I., Hassan, S., Cik, A. R. \& Yahya, M. A. (2010) latihan mengajar menjadi keperluan dalam kursus perguruan bagi membolehkan guru pelatih mendapat pengalaman dengan merasai persekitaran kerja yang sebenar malah guru pelatih juga mendapat pendedahan awal yang amat bernilai. Guru pelatih yang kekurangan pengalaman mempunyai kebarangkalian yang tinggi untuk gagal dalam menyampaikan pengajaran yang interaktif dan bermakna kepada pelajar (ZembelSaul, C., Blumenfeld, P. \& Krajcok, J., 2000). Namun, Raths, J, (2000) berpandangan bahawa terdapat juga masalah yang berkaitan program pendidikan keguruan yang tidak efektif dalam menambah baik amalan latihan mengajar. Oleh yang demikian, guru pelatih berhadapan dengan masalah besar dalam usaha belajar untuk mengajar dan memperbaiki pengajaran (Kasa, Z., Asimirin, S., 
Jamian, A. R. \& Othman, Y, 2001). Fokus permasalahan merujuk kajian ini ditumpukan kepada upaya guru pelatih berbahasa khususnya BMTB kerana golongan ini merupakan sasaran utama untuk menjadi guru yang berwibawa dan profesional kelak. Guru pelatih seharusnya berupaya menunjukkan kredibiliti dan potensi serta kompetensi BMTB yang tinggi. Secara telusnya, kajian ini berkaitan masalah upaya berbahasa atau masalah komunikasi guru perlu ditangani dari awal sejak menjadi guru pelatih lagi.

\section{OBJEKTIF KAJIAN}

Secara khususnya, objektif kajian ini adalah untuk:

1. mengenal pasti upaya berbahasa guru pelatih dalam bidang Bahasa Melayu menerusi kesantunan berbahasa berdasarkan skala morfofonetik, skala sosiolinguistik dan skala sosiopragmatik.

2. membincangkan upaya berbahasa guru pelatih menerusi kesantunan berbahasa sebagai indikator profesionalisme guru pelatih dalam pengajaran bahasa Melayu dalam konteks keperluan negara dalam pembangunan pendidikan kebangsaan.

\section{METODOLOGI}

\section{Sampel}

Kajian ini menggunakan sembilan orang guru pelatih Bahasa Melayu yang menjalani latihan mengajar di lima buah sekolah menengah terpilih di Perak, iaitu:

i. Sekolah Menengah Kebangsaan Bandar Baharu Behrang 2020, Behrang,

ii. Sekolah Menengah Kebangsaan Sg Kruit, Sungkai,

iii. Sekolah Menengah Kebangsaan Slim, Slim River,

iv. Sekolah Menengah Kebangsaan Seri Setia, Teluk Intan dan

v. Sekolah Menengah Kebangsaan Seri Perak, Teluk Intan.

Sampel kajian dipilih dalam kalangan guru pelatih yang diselia sendiri oleh ketua penyelidik dan penyelidik bersama. Sampel kajian ini dipilih melalui kaedah persampelan bertujuan (purposive sampling) yang melibatkan pertimbangan pengkaji berdasarkan pengetahuan 
dan tujuan khusus kajian. Hal ini demikian kerana kajian kualitatif dikategorikan sebagai particularistic yang lebih menumpukan situasi, program dan fenomenon tertentu sahaja yang berpusatkan masalah dan berskala kecil (Shaw, 1978; Meriam, 2001). Pemilihan sampel ini berdasarkan kepada pembahagian pelajar yang menjalani latihan mengajar oleh pihak Jabatan Bahasa dan Kesusasteraan Melayu, Fakulti Bahasa dan Komunikasi, Universiti Pendidikan Sultan Idris. Kesemua pensyarah dari jabatan berkenaan memperoleh jumlah pelajar yang sama rata dan daripada pembahagian ini. Pemilihan sampel sebagai indikator profesionalisme dalam kajian ini dilakukan berlatarbekangkan beberapa ciri berikut, iaitu i) pelajar praktikum tahun akhir (Semester 7), ii) Jurusan Program Bahasa Melayu dan iii) pelajar-pelajar praktikum di bawah seliaan penyelidik.

Jelasnya, kajian kualitatif tidak memerlukan bilangan responden yang ramai tetapi maklumat yang diperoleh berkualiti dengan memberi fokus terhadap sampel yang kecil dalam kumpulan (Hamzah, 2010) dan pemerhatian yang dijalankan bersifat semula jadi yang mementingkan realiti, bersifat fenomenologis serta memiliki hubungan langsung dengan data yang diteliti, iaitu penyelidik turut terlibat menerusi proses pemerhatian terhadap peristiwa interaktif tersebut (Neuman, 2006).

Latar belakang pelajar latihan mengajar pula terdiri daripada pelajar yang telah mengikuti pengajian selama enam semester dalam bidang pengkhususan mereka, iaitu Pendidikan Bahasa Melayu dan memiliki kemahiran dan tahap pendedahan kepada ilmu linguistik Melayu yang sama.

\section{Reka Bentuk}

Menurut Neuman (2006) penyelidikan kualitatif sememangnya bersifat fenomenalogis yang berfokuskan peristiwa interakif serta melibatkan pemerhatian secara semula jadi atau realiti. Reka bentuk kajian ini berasaskan kajian penyelidikan kualitatif bukan eksperimental. Kajian yang bersifat kualitatif ini menyokong kefahaman yang mendalam dan menyeluruh berkaitan sesuatu fenomena. Kompleksiti pemahaman yang terdapat dalam sesuatu fenomena dapat ditangani dengan adanya pendeskripsian yang tuntas dan komprehensif.

Fenomena yang diteliti daripada pencerapan PdPc guru pelatih dilihat berdasarkan upaya berbahasa Melayu tinggi dan berbudaya 
berasaskan skala morfofonetik, skala sosiolinguistik dan skala sosiopragmatik sebagai Indikator Profesionalisme Guru Pelatih. Penelitian kualitatif deskriptif digunakan berdasarkan kerangka konseptual khusus (Rujuk Rajah 1) dengan tujuan untuk mentafsirkan dan menghuraikan data yang bersangkutan upaya berbahasa guru pelatih dari perspektif morfofonetik yang menjurus kepadapematuhan aspek sebutan perkataan dalam bahasa Melayu baku; mengenal pasti upaya berbahasa guru pelatih dari perspektif sosiolinguistik, iaitu khusus kepada pemilihan dan penggunaan Bahasa Melayu Tinggi yang sesuai, rapi dan tidak mengandungi percampuran kod dan penggunaan Bahasa Melayu Rendah; dan mengenal pasti upaya berbahasa guru pelatih dari perspektif sosiopragmatik meliputi aspek strategi kesantunan berbahasa dalam amalan sebenar guru pelatih menerusi pemerhatian pengkaji terhadap pencerapan PdPc yang dirakam.

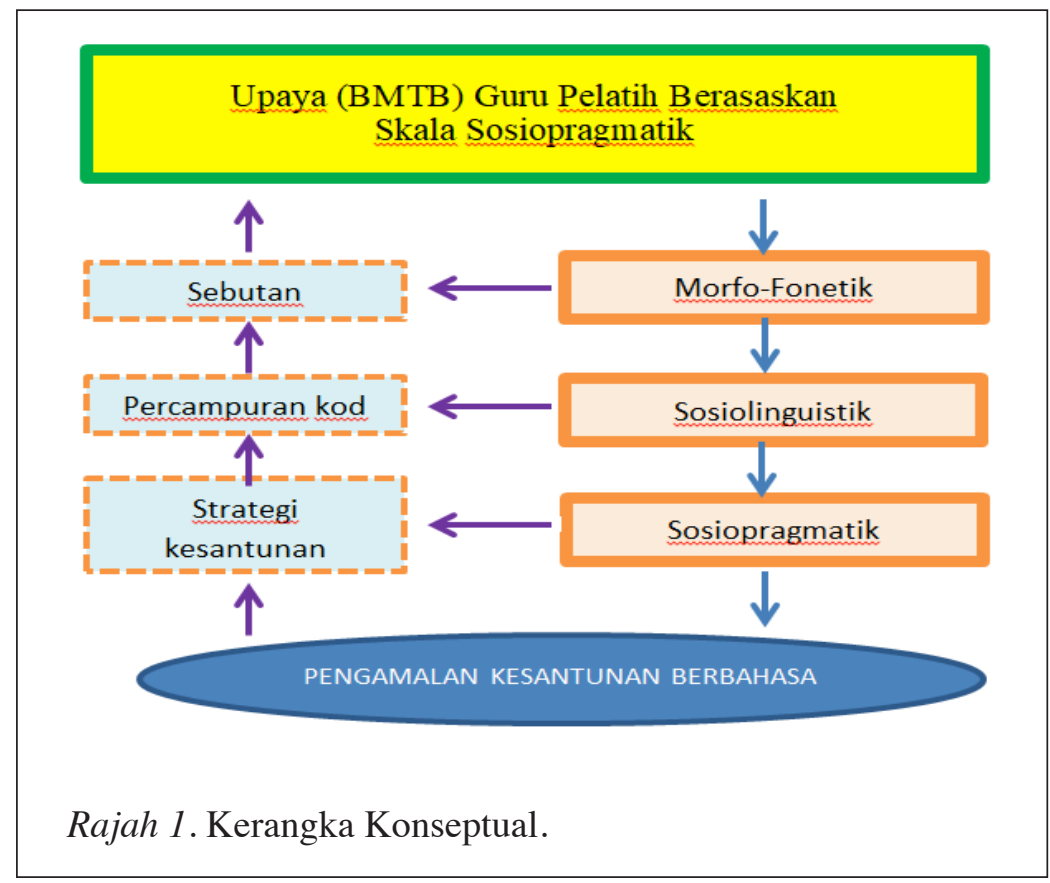

\section{Instrumen}

Menurut Fraenkel dan Wallen (1996) kesahan instrumen perlu mempunyai fitur seperti dapat dipertahankan (defensibility), mempunyai ketepatan (accuracy), mempunyai kesesuaian 
(appropriateness), bermakna(meaningfulness)danberkebolehgunaan (usefulness). Kebolehpercayaan pula ialah ketekalan dan kestabilan sesuatu alat kajian (Marican, 2005). Dalam kajian ini, kesahan dan kebolehpercayaan instrumen telah diperaku dan disahkan oleh tiga orang pakar bidang. Setelah semua hasil transkripsi dan instrumen disahkan, pengkaji menyusun tadbir data mengikut objektif kajian yang hendak dicapai menggunakan instrumen tersebut secara sistematik. Pengesahan instrumen daripada pakar bidang diperoleh bagi memastikan kesahan dan kebolehpercayaan instrumen kajian ini diperaku. Tambahan pula, menurut Cohen, Manion dan Morrison (2000) persetujuan pakar penting kerana pakar merupakan interrater . Kobolehpercayaan interraters menunjukkan darjah persetujuan yang diperoleh secara konsensus yang wujud secara homogen dalam kalangan pakar bidang atau penilai (raters).

Instrumen kajian terdiri daripada bahan rakaman PdPc yang ditranskripsikan dan dianalisis menggunakan skala mofofonetik, sosiolinguitik dan sosiopragmatik. Administrasi alat kajian tersebut adalah seperti yang ditunjukkan dalam Rajah 2 berikut:

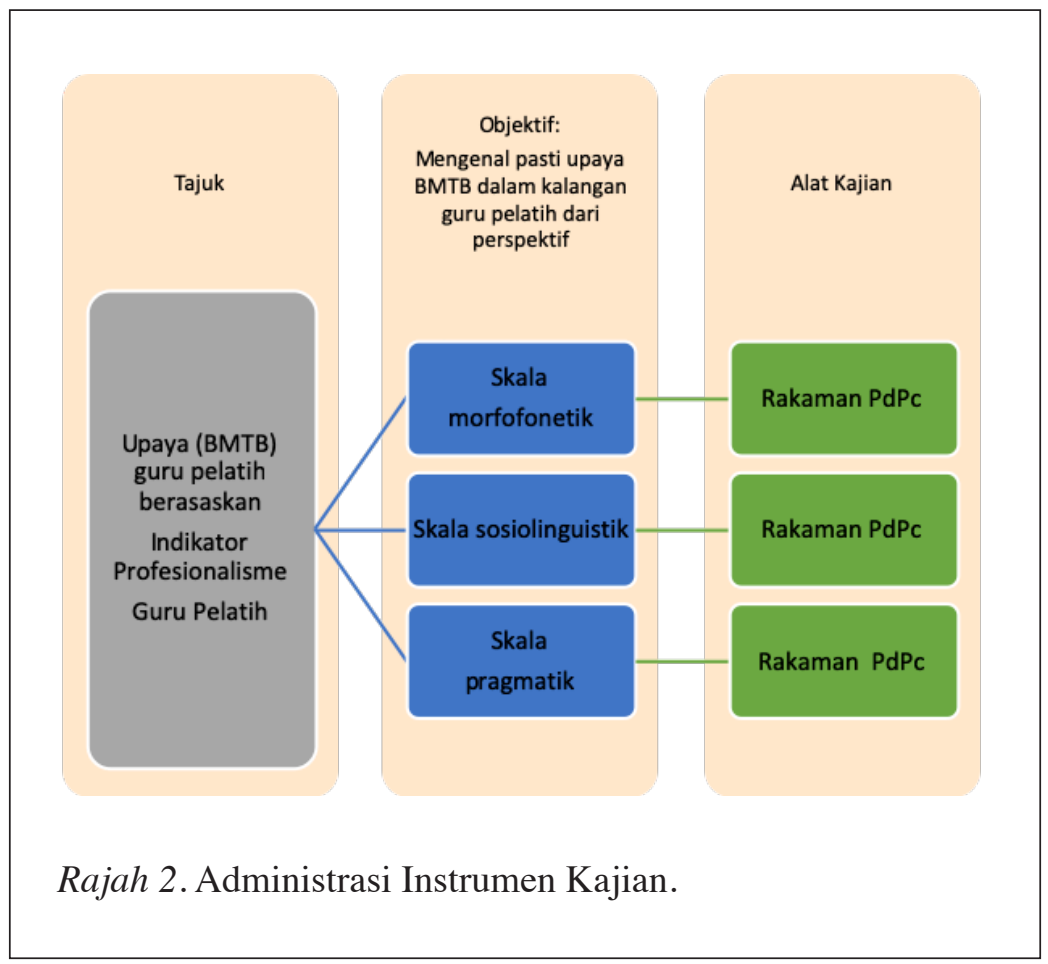


Proses pencerapan dilakukan melalui beberapa peringkat pengurusan seperti mendapatkan persetujuan responden terlebih dahulu serta memaklumkan kepada mereka berkaitan pelaksanaan kajian ini secara terperinci agar mereka dapat memberi kerjasama dengan sebaik-baiknya. Bagi memenuhi keperluan mematuhi etika penyelidikan, nama sampel dan nama kelas diklasifikasikan sebagai sulit bagi melindungi privasi dan kepentingan kedua-dua guru pelatih dan murid yang belajar di dalam kelas-kelas berkenaan.

Kemudian, pencerapan PdPc dirakamkan dalam video dan ditranskripsikan. Pencerapan dilakukan sebanyak satu kali sahaja, iaitu pada penyeliaan pertama latihan mengajar dan mengambil masa satu jam bagi setiap sesi PdPc guru pelatih. Durasi masa rakaman PdPc bagi sembilan guru pelatih berjumlah 540 minit. Analisis transkripsi pencerapan PdPc dilakukan dengan merujuk Indikator Profesionalisme Guru Pelatih yang diukur menerusi skala morfofonetik, skala sosiolinguistik dan skala sosiopragmatik. Setiap rakaman yang ditranskripsi diulang dengar sekurangkurangnya tiga kali bagi memastikan tiada bahagian rakaman yang tertinggal. Prosedur berikutnya ialah mendapatkan kesahan data yang telah dilaksanakan oleh pakar bidang. Prosedur ini dilakukan bagi memastikan data yang diperoleh dan dianalisis adalah benar dan melalui proses analisis yang bertepatan dengan kaedah yang dicadangkan. Selain itu, prosedur ini signifikan kepada penyelidik bagi memastikan data yang diperoleh memiliki ciri-ciri yang dikehendaki dalam kajian ini yang seterusnya memastikan objektif kajian dapat dicapai.

\section{Kerangka Teori}

Kertas kerja ini mengaplikasikan teori Kesantunan Berbahasa(Brown \& Levinson, 1987) dalam mendeskripsikan gelagat serta amalan kesantunan berbahasa oleh guru pelatih dalam sesi PdPc. Brown dan Levinson (1987:62) mengaitkan kesantunan sebagai usaha untuk meminimumkan Lakuan Ancaman Muka (Face Threatening Act) kepada pendengar dengan mengemukakan Teori Kesantunan Linguistik yang terdiri daripada 5 strategi utama, iaitu strategi secara langsung (Bald on Record), kesantunan positif (Positive Politeness), kesantunan negatif (Negative Politeness), strategi tidak langsung (Off Record) dan strategi memilih untuk tidak melakukan sebarang lakuan ancaman muka (Rujuk Rajah 3). Walau bagaimanapun dalam kajian ini, kesantunan negatif tidak dibincangkan. 


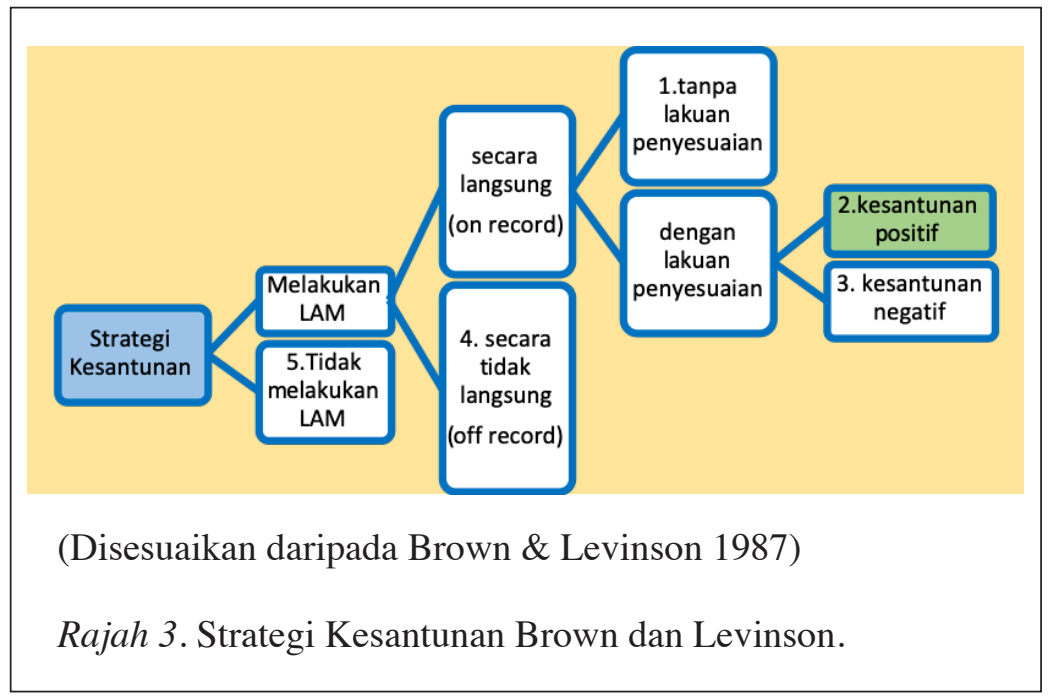

Secara khususnya, Strategi Kesantunan Positif yang digunakan oleh guru pelatih sahaja yang menjadi fokus kajian. Strategi Kesantunan Positif tersebut ditunjukkan dalam Rajah 4 yang berikut:

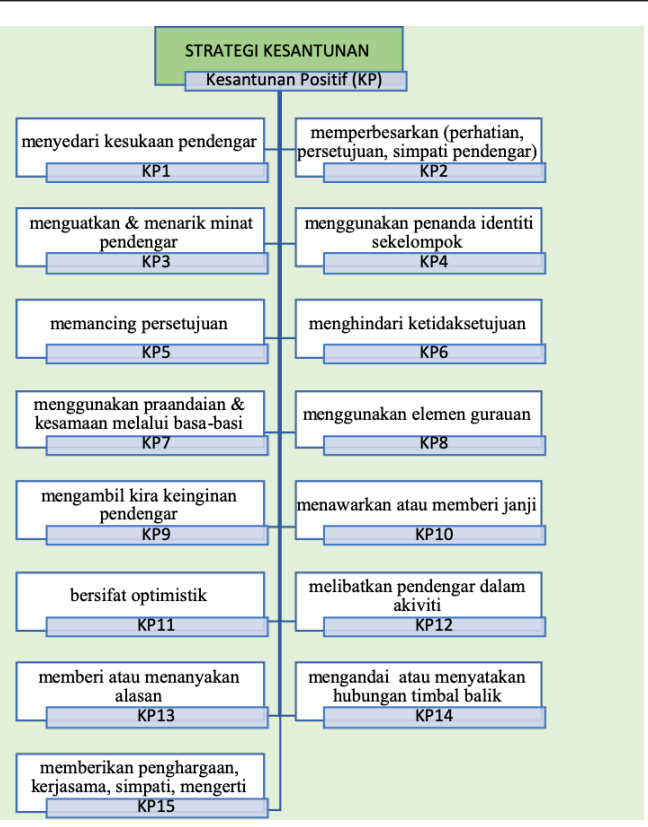

(Disesuaikan daripada Brown \& Levinson, 1987)

Rajah 4. Strategi Kesantunan Positif. 


\title{
DAPATAN KAJIAN DAN PERBINCANGAN
}

Bahagian ini akan membincangkan dapatan kajian berdasarkan objektif kajian yang dibangunkan dalam kajian ini. Dalam kertas kerja ini, kesantunan berbahasa sebagai indikator profesionalisme guru pelatih atau bakal pendidik relevan dan harus diberi penekanan, dititikberatkan dan ditingkatkan serta diteruskan amalannya dalam kalangan guru pelatih sebagai persediaan menjadi guru terlatih kelak.

Upaya Berbahasa Guru Pelatih Menerusi Skala Morfofonetik, Sosiolinguistik dan Sosiopragmatik

\section{Upaya BMTB dari Sudut Morfofonetik}

Upaya BMTB dari sudut morfofonetik dalam kalangan guru pelatih dapat diteliti dari sudut kepatuhan mereka dalam mengartikulasikan perkataan-perkataan dalam bahasa Melayu dengan menggunakan sebutan yang baku. Namun, ketidakpatuhan terhadap aspek ini biasa berlaku dalam kalangan pengguna bahasa, iaitu berlakunya penambahan fonem, perubahan fonem dan pengguguran fonem.

Berdasarkan kajian ini, didapati bahawa ketidakpatuhan terhadap aspek morfofonetik BMTB dikenal pasti berlaku dari aspek perubahan fonem /l/ menjadi / $\mathrm{P} /$, pengguguran fonem /r/ pada akhir kata dan pengguguran fonem $/ \mathrm{h} /$ pada akhir kata yang diujarkan oleh guru pelatih dalam sesi PdPc seperti dalam contoh ujaran yang berikut:

Jadual 1.

Ketidakpatuhan Aspek Morfofonetik BMTB dalam Kalangan Guru Pelatih

\author{
Ketidakpatuhan aspek Contoh Ujaran \\ morfofonetik
}

Penambahan fonem /?/

/ambel/ à /ambe?/

Seorang ketua datang sini ambik!

Ambik ni. 
Ketidakpatuhan aspek Contoh Ujaran morfofonetik

\begin{tabular}{|c|c|}
\hline /kəčil/ à /kəči?/ & Kecik pulak! \\
\hline /buka/ à /buka?/ & $\begin{array}{l}\text { Cikgu nak kamu bukak sampul itu } \\
\text { dan lekatkan gambar dalam sampul itu } \\
\text { mengikut kelas. }\end{array}$ \\
\hline /pula/ à /pula?/ & $\begin{array}{l}\text { Ibu bapa? Boleh diterima. Okey budak- } \\
\text { budak. Budak-budak pulak. Pelajar sepe } \\
\text { kamu makan banyak sebab kamu masih } \\
\text { nak membesar. }\end{array}$ \\
\hline /biji/ à /biji?/ & $\begin{array}{l}\text { Macam mana langkah-langkah dia? } \\
\text { Ambil berapa? Kamu nak ambil berapa } \\
\text { bijik? }\end{array}$ \\
\hline
\end{tabular}

/buka/ à /buka?/

Tengok dalam buku PJ kamu. Tadi kamu dah bukakkan.

\section{Pengguguran fonem \\ $/ \mathbf{r} /$}

/bəlaǰar/ à /bəlaǰa/

Sebelum ni kamu ada belaja kata ganda, bukan?

/bəsar/ à /bəsa/

Kebiasaannya undang-undang ni kita gunakan untuk perkara yang besa. Undangundang negara, undang-undang jalan raya.

\section{Pengguguran fonem \\ /h/}

/lah/ à /la/

Betul-betul $\boldsymbol{l a}$.

Cepatla buat. Alia kamu boleh duduk.

Terima kasih Alia.

Kito? Kita la bukan kito.

Jelasnya, bahasa yang teratur rapi dan berkesan dalam konteks rasmi ialah bahasa baku. Sebagai guru pelatih apatah lagi guru terlatih tidak wajar menurunkan darjat bahasa Melayu yang sudah mencapai taraf yang tinggi khususnya dalam aspek sebutan dengan mencemarkannya 
dengan sebutan bahasa Melayu rendah apabila berkomunikasi dalam konteks rasmi, seperti di dalam bilik darjah misalnya. Berdasarkan data yang diperoleh, guru pelatih didapati berupaya menggunakan sebutan baku serta ujarannya tidak dipengaruhi oleh dialek mahupun bahasa ibunda mereka. Namun, pengaruh bahasa basahan masih wujud dalam penggunaan bahasa mereka. Sungguhpun begitu, kelemahan ini boleh diatasi sekiranya kesedaran akan pentingnya mengamalkan sebutan baku ini sering dititikberatkan dalam kursus yang mereka ikuti sepanjang pengajian mereka. Jelasnya, aspek morfofonetik ini sangat penting kerana aspek ini merupakan salah satu indikator profesionalisme sebagai pendidik. Keupayaan guru untuk mengaplikasi ilmu dan memastikan murid menuruti ilmu yang diajarkan semasa PdPc berlangsung menjadi tanda bahawa guru menguasai BMTB serta menjadi pemangkin kepada kemahiran murid untuk berbahasa dengan baik.

\section{Upaya BMTB dari Sudut Sosiolinguistik}

Upaya BMTB dari sudut sosiolinguistik dalam kalangan guru pelatih dapat diteliti dari sudut kepatuhan mereka terhadap peraturan sosiolinguistik, iaitu dalam mengajarkan subjek Bahasa Melayu dengan menggunakan bahasa yang rapi dan tidak mengandungi percampuran kod. Percampuran kod boleh berlaku akibat daripada penguasaan dua bahasa mahupun lebih. Namun, guru seharusnya bijak menggunakan bahasa tinggi dalam konteks rasmi dan bahasa rendah dalam konteks tidak rasmi.

Kemahiran sosiolinguistik dan kemahiran komunikatif wajar disepadukan dalam kalangan guru pelatih. Bahasa Melayu mengalami kekangan untuk dimartabatkan jika guru-guru yang mengajar mata pelajaran tersebut tidak menggunakan bahasa Melayu dengan betul (Mahmood, 2002). Beliau menambah melalui kajiannya menunjukkan bahawa masih ramai guru yang menggunakan dialek setempat semasa mengajar mata pelajaran Bahasa Melayu dan tidak menggunakan bahasa baku.

Namun begitu, dari sisi lain pula, harus dibezakan fenomena penyerapan kata atau leksis khusus dalam dialek atau bahasa sukuan dengan fenomena percampuran kod yang berlaku secara tidak langsung dalam bahasa Melayu walaupun kedua-duanya kelihatan 
hampir sama. Yang mengikat kewujudan setiap leksis dalam bahasa Melayu bersama-sama leksis bahasa sukuan itu ialah unsur tradisi yang cuba dikekalkan untuk menggambarkan kehidupan etnik yang melatarinya (Yusuff, Sarudin \& Jamaluddin, 2017). Fenomena penyerapan dilihat sebagai elemen pengayaan bahasa, manakala fenomena percampuran kod dilihat sebagai indikator wujudnya kecelaruan bahasa. Jelasnya, representasi penyerapan kata dan percampuran kod berbeza kerana latar dan motivasi bagi kewujudan penyerapan kata dan percampuran kod itu sendiri juga berbeza.

Apabila berlakunya percampuran kod, penggunaan BMTB kurang diamalkan. Selain pengaruh dialek atau bahasa sukuan, didapati bahawa kekacauan atau gangguan bahasa juga berlaku ditambah dengan pengaruh slanga dan bahasa basahan. Slanga cepat tumbuh dan cepat pupus selari dengan peredaran masa. Sungguhpun begitu slanga tetap wujud, berleluasa dan memberi cabaran dalam usaha memartabatkan BMTB. Bahasa basahan pula yang selalu diucapkan dalam perbualan harian juga mempengaruhi penggunaan BMTB dalam konteks rasmi. Percampuran pelbagai variasi ini mewujudkan fenomena percampuran kod.

Fenomena wujudnya perkataan atau frasa daripada bahasa asing dalam bahasa yang dituturkan dinamakan percampuran kod. Campur kod juga tergolong dalam bahasa rojak (Omar, 2007). Dalam sesuatu pertuturan atau perbualan, sama ada antara kaum yang berbeza, seperti dalam filem dan pekerjaan atau profesion seseorang, boleh berlaku salah satunya dan boleh berlaku kedua-duanya (Omar, 2007). Dalam kajian ini, ditunjukkan fenomena percampuran kod yang berlaku antara BMTB dan bahasa Inggeris dan BMTB dengan bahasa basahan adalah seperti berikut:

\section{Percampuran Kod antara BMTB dengan Bahasa Inggeris}

Berdasarkan kajian ini, percampuran kod yang paling ketara didapati berlaku dalam PdPc dalam kalangan guru pelatih adalah penggunaan kata Inggeris okey. Kata Inggeris okey ini sewajarnya digantikan dengan penggunaan kata baik. Contoh penggunaan kata okey tersebut ditunjukkan seperti yang ditunjukkan dalam Jadual 2 yang berikut: 
Jadual 2.

Ujaran yang Kerap Mengandungi Percampuran Kod BMTB dan Bahasa Inggeris dalam Kalangan Guru Pelatih

\begin{tabular}{ll}
\hline Bahasa Inggeris & Contoh Ujaran \\
\hline Okey & Okey. Aaa... Kiranya ini adalah ulang kaji sebe- \\
& lum peperiksaan 23 Ogos, kan? Betul? \\
& Okey sekarang. Fokus. Bagi tumpuan dengan \\
& lagu yang akan cikgu pasangkan. \\
& Okey... lagi? Yang ini kelas? Okey tak? \\
\hline
\end{tabular}

Selain itu, terdapat juga percampuran kod yang berlaku dalam PdPc dalam kalangan guru pelatih, iaitu penggunaan kata Inggeris seperti viral, senior dan purple. Perkataan-perkataan tersebut masingmasing sewajarnya digantikan kepada perkataan tular, pelajar lama dan ungu yang dapat diteliti dalam Jadual 3 yang berikut:

Jadual 3.

Ujaran yang Mengandungi Percampuran Kod BMTB dan Bahasa Inggeris dalam Kalangan Guru Pelatih

\begin{tabular}{ll}
\hline Bahasa Inggeris & Contoh Ujaran \\
\hline viral & $\begin{array}{l}\text { Polis sedang menyiasat kes video viral seorang } \\
\text { perempuan dibuli sekumpulan pelajar perempuan } \\
\text { lain. }\end{array}$ \\
senior & $\begin{array}{l}\text { Kamu pernah nampak tak senior, aaa abang-abang } \\
\text { kamu ke, rakan-rakan kamu ke buat benda-benda } \\
\text { macam ni? }\end{array}$ \\
purple & Eh semua purple ke? \\
\hline
\end{tabular}

\section{Percampuran Kod antara BMTB dengan Bahasa Basahan}

Fenomena percampuran kod khususnya percampuran kod BMTB dengan kod kata singkatan menunjukkan masih terdapat ketidakpatuhan terhadap peraturan penggunaan BMTB dalam kalangan guru pelatih. Contohnya penggunaan kata singkatan seperti tau, tak, tak pa, bagitau, dah, nak, ni, je, tu, lepas tu dan tak de la seperti di dalam Jadual 4 yang berikut: 
Jadual 4

Percampuran Kod antara BMTB dengan Bahasa Basahan (Kata Singkatan) dalam Kalangan Guru Pelatih

\begin{tabular}{ll}
\hline Kata Singkatan & Contoh Ujaran \\
\hline tahu à tau & Haa? Boleh. Kalau kamu tau, kamu boleh \\
& nyanyi sekali. Okey, sedia! Sedia dengar \\
& lagu. \\
tidak à tak & Seronok? Seronok tak dengar lagu ni? \\
tidak mengapa à tak pa & Tak pa, lain kali kita akan dengar lagu ni. \\
beritahu à bagitau & Boleh bagitau dengan cikgu dan kelas salah \\
& satu contoh kata ganda yang ada dalam lirik \\
& lagu? \\
sudah à dah & Baik. dah... dah... tanda kata nama ganda \\
yang terdapat dalam lirik lagu? & Cikgu nak semak dulu. \\
hendak à nak & Pernah dengar tak lagu ni? \\
ini à ni & Cikgu bagi masa 5 minit je. Lima minit je. \\
sahajaà je & Tu la, main lagi kan dah tak tau nak jawab. \\
itu à tu & Nah, yang terakhir. \\
selepas itu à lepas tu & Cikgu dah sediakan kertas mahjong, lepas tu \\
ada petikan.
\end{tabular}

Tidak ada lah à tak de la Tak de la kelas awak kotor, kan.

Selain itu, percampuran kod yang sering berlaku ialah percampuran bahasa tinggi dengan bahasa rendah yang dikenal pasti terdapat dalam data kajian ini ialah penggunaan kata kena, bagi, dekat, ambik, bagitau, kat, amik, la seperti dalam contoh yang ditunjukkan dalam Jadual 5. Perkataan basahan yang digunakan oleh guru pelatih tersebut juga diberikan alternatif perkataan yang dalam bentuk yang betul atau yang sewajarnya digunakan.

Jelasnya, campur aduk dua bahasa atau lebih mencerminkan pemikiran yang celaru dan bahasanya juga tidak bersistem atau tidak rapi. Berdasarkan data yang diperoleh, didapati bahawa guru pelatih jarang menggunakan percampuran kod dalam interaksi mereka 
dalam bilik darjah terutamanya dalam sesi PdPc. Namun begitu, terdapat percampuran kod antara BMTB dengan bahasa Inggeris serta percampuran kod antara BMTB dengan bahasa basahan. Sungguhpun begitu percampuran kod ini tidaklah dominan dan masih boleh dikawal. Didapati bahawa tidak berlaku percampuran kod antara BMTB dengan bahasa Melayu rendah seperti dialek atau slanga dalam kalangan guru pelatih. Ini menunjukkan bahawa percampuran kod tidak berlaku secara berleluasa dan masih boleh dikawal. Namun, seboleh-bolehnya mahu tidak mahu, guru pelatih sedaya upaya sewajarnya mampu menggunakan BMTB tanpa berlaku percampuan kod kerana ciri ini merupakan indikator penting profesionalisme pendidik.

Jadual 5

Percampuran Kod antara BMTB dengan Bahasa Basahan dalam Kalangan Guru Pelatih

\begin{tabular}{lll}
\hline Bahasa Basahan & BMTB & Contoh Ujaran \\
\hline kena & perlu & Kamu kena banyak tidur, \\
bagi & beri & Kertas yang cikgu bagi tadi mana? \\
dekat & di & Tolong pergi dekat kamu punya hasil. \\
ambik & ambil & $\begin{array}{l}\text { Kamu ada } \text { ambik tak makanan seperti } \\
\text { dalam piramid makanan tu? }\end{array}$ \\
bagitau & beritahu & $\begin{array}{l}\text { Bagitau cikgu apa yang kamu dah } \\
\text { belajar hari ni? }\end{array}$ \\
kat & dekat & Datang kat cikgu sini. \\
amik & ambil & Amik sorang satu. \\
la & lah & Amik $\boldsymbol{l a}$ warna apa pun. \\
\hline
\end{tabular}

\section{Upaya Berbahasa Guru Pelatih dari Perspektif Sosiopragmatik}

Dalam meneliti aspek upaya guru pelatih dari perspektif sosiopragmatik, Teori Kesantunan Berbahasa (Brown \& Levinson, 1987) diaplikasikan dalam mendeskripsikan gelagat serta amalan kesantunan berbahasa khususnya dari sudut sosiopragmatik dalam kalangan guru pelatih dalam sesi PdPc. 
Brown dan Levinson (1987) mengaitkan kesantunan sebagai usaha untuk meminimumkan Lakuan Ancaman Muka (Face Threatening Act) kepada pendengar dengan mengemukakan Teori Kesantunan Linguistik yang terdiri daripada 5 strategi utama, iaitu Strategi Secara Langsung (Bald on Record), Kesantunan Positif (Positive Politeness), Kesantunan Negatif (Negative Politeness), Strategi Tidak Langsung (Off Record) dan Strategi Memilih untuk Tidak Melakukan Lakuan Ancaman Muka (Rujuk Rajah 3). Dalam kajian ini, aspek Strategi Kesantunan Positif dan dalam kalangan guru pelatih diberikan tumpuan.

\section{Strategi Kesantunan Positif}

Strategi Kesantunan Positif dalam Pendekatan Brown dan Levinson (1987) merujuk kepada setiap manusia mempunyai muka yang merujuk kepada imej kendiri individu yang ada kaitan dengan emosi dan pemikiran sosial seseorang yang sering menjangkakan yang dirinya diterima oleh khalayak. Brown dan Levinson (1987) menyatakan bahawa Kesantunan Positif juga merujuk kepada muka positif, iaitu keinginan individu untuk disukai dan diterima oleh khalayak atau untuk maksud sebaliknya individu itu menyedari pendengar berkeinginan untuk dihargai. Menurutnya lagi, Kesantunan Positif seperti membenarkan setiap individu untuk mempertahankan hak, tidak bergantung dan diganggu oleh orang lain. Strategi Kesantunan Positif yang digagaskan dalam kajian ini dinyatakan seperti dalam Rajah 4. Dalam kebanyakan perkara, muka berhadapan dengan risiko akibat tindakan yang dilakukan oleh seseorang. Lazimnya, individu akan mengimbangi ujaran yang dituturkan dengan pembentukan bentuk bahasa, misalnya bentuk bahasa yang lebih lembut dan santun bertujuan tidak menyakiti individu terbabit (Abdul Aziz, 2010).

Jelasnya, berdasarkan dapatan yang diperoleh, Strategi Kesantunan Positif yang digunakan oleh guru pelatih dalam interaksi dalam kelas semasa proses PdPc telah dilaksanakan dan didapati bahawa amalan tersebut meliputi semua Substrategi Kesantunan Positif (KP1 -KP15) iaitu, menyedari kesukaan pendengar (KP1); memperbesarkan (perhatian, persetujuan, simpati pendengar; menguatkan \& menarik minat pendengar (KP3); menggunakan penanda identiti sekelompok (KP4); memancing persetujuan (KP5); menghindari ketidaksetujuan (KP6); praandaian \& kesamaan melalui 
basa-basi (KP7); menggunakan elemen gurauan (KP8); mengambil kira keinginan pendengar (KP9); menawarkan atau memberi janji (KP10); bersifat optimistik (KP11); melibatkan pendengar dalam akiviti (KP12); memberi atau menanyakan alasan (KP13); mengandai atau menyatakan hubungan timbal balik (KP14) dan; memberikan penghargaan, kerjasama, simpati, mengerti (KP15) seperti yang dianjurkan oleh Brown dan Levinson (1987). Strategi Kesantunan Positif dikenal pasti hadir mengikut fasa pengajaran, iaitu fasa permulaan, fasa perkembangan dan fasa penutup pengajaran.

\section{Fasa Permulaan Pengajaran}

Berdasarkan kajian, didapati bahawa terdapat lima Substrategi Kesantunan Positif yang digunakan oleh guru pelatih dalam sesi permulaan pengajaran. Substrategi tersebut merangkumi substrategi menyedari kesukaan pendengar (KP1), memperbesarkan perhatian terhadap pendengar (KP2), menarik minat pendengar (KP3), memancing persetujuan pendengar (KP5) dan menghindari ketidaksetujuan pendengar (KP6). Contoh ujaran yang mengandungi Strategi Kesantunan Positif melalui substrateginya mengikut konteks dan peristiwa bahasa berdasarkan data kajian adalah seperti yang berikut:

\section{Substrategi KPI}

Ekstrak 1

Konteks:

Guru menggunakan basa-basi pada fasa permulaan pengajaran dengan menanyakan kesediaan pelajar.

\begin{tabular}{|c|c|}
\hline Guru: & $\begin{array}{l}\text { Kutip sampah-sampah yang ada. Banyak sampah yang } \\
\text { cikgu Nampak. Kutip sampah-sampah yang ada di } \\
\text { sekeliling awak tu. Dah habis kutip? Boleh kita belajar? }\end{array}$ \\
\hline Pelajar: & Boleh. (Pelajar menjawab beramai-ramai) \\
\hline
\end{tabular}

\section{Substrategi KP2}

Ekstrak 2

Konteks:

Guru memperbesar perhatian dengan meminta kepastian sama ada pelajarnya sudah makan atau belum sebelum memulakan sesi pengajaran. 

Guru:
Dah makan?
Pelajar:
Dah. (Pelajar menjawab beramai-ramai)
Guru:
Betul?
Pelajar:
Betul. (Pelajar menjawab beramai-ramai)

\title{
3. $\quad$ Substrategi KP3
}

\section{Ekstrak 3}

Konteks:

Guru menarik minat pelajar semasa sesi induksi dengan meminta pelajar meneka topik pelajaran mereka.

\section{Guru: \\ Okey, hari ini kita akan belajar ulasan, tapi cikgu nak kamu tekalah apa yang kita akan belajar hari ini, boleh?}

\section{Substrategi KP5}

Ekstrak 4

Konteks:

Guru memancing persetujuan pelajar apabila meminta pelajar melaksanakan tugasan ringkas dalam sesi induksi.

Guru: Jadi, kamu akan dengar dulu lagu yang cikgu akan pasang dan lihat lirik. Sambil kmu dengar lagu, lihar lirik kamu. Kemudian, kamu kesan dan keluarkan kata ganda yang terdapat dalam lirik tersebut. Boleh?

\section{Substrategi KP6}

\section{Ekstrak 5}

Konteks:

Guru menghindar ketidaksetujuan apabila pelajar meminta untuk menyanyi bersama apabila guru memainkan lagu.

\author{
Pelajar: \\ Cikgu, boleh nyanyi sekali? \\ Guru: \\ Ha? Boleh. Kalau kamu tau, kamu boleh nyanyi \\ sekali. Okey, sedia! Sedia dengar lagu.
}


Berdasarkan kajian, didapati bahawa terdapat 12 Substrategi Kesantunan Positif yang digunakan oleh guru pelatih dalam sesi perkembangan pengajaran. Substrategi tersebut merangkumi substrategimenggunakan kataidentitisekelompok(KP4), memancing persetujuan pendengar (KP5) dan menghindari ketidaksetujuan pendengar (KP6), menggunakan praandaian dan kesamaan melalui basa-basi (KP7), menggunakan elemen gurauan (KP8), mengambil kira keinginan pendengar (KP9), menawar atau memberi janji (KP10), bersifat optimistik (KP11), melibatkan pendengar dengan aktiviti (KP12), memberi alasan (KP13), mengandai atau menyatakan hubungan timbal balik (KP14) dan memberi penghargaan (KP15). Contoh ujaran yang mengandungi Strategi Kesantunan Positif melalui substrateginya mengikut konteks dan peristiwa bahasa berdasarkan data kajian adalah seperti yang ditunjukkan berikut:

\section{Substrategi KP4}

Ekstrak 6

Konteks:

Guru menggunakan penanda identiti sekelompok 'bagitau eh' sebelum menyampaikan isi kandungan pelajaran. Contoh ujarannya ialah:

Guru: Okey, cikgu bagitau eh.

\section{Substrategi KP5}

Ekstrak 7

Konteks:

Guru memancing persetujuan pelajar apabila meminta pelajar melaksanakan tugasan sebagai pengukuhan pada akhir pengajaran. Contoh ujarannya ialah:

$\begin{array}{ll}\text { Guru: } & \begin{array}{l}\text { Cikgu nak kamu semua hasilkan satu ulasan yang } \\ \text { lengkap sebagai kerja rumah, boleh tak? }\end{array} \\ \text { Pelajar: } & \text { Boleh (Pelajar menjawab beramai-ramai) }\end{array}$




\section{3. $\quad$ Substrategi KP6}

Ekstrak 8

Konteks:

Guru menghindari ketidaksetujuan apabila pelajar bertanyakan cara untuk melaksanakan aktiviti apabila belum tiba masanya.
Pelajar:
Cikgu, ni nak buat apa?
Guru:
Nanti, cikgu terangkan.

\section{4. $\quad$ Substrategi KP7}

Ekstrak 9

Konteks:

Guru membuat praandaian dan kesamaan melalui basa-basi apabila mengaitkan dengan isi kandungan.

$\begin{array}{ll}\text { Guru: } & \begin{array}{l}\text { Kes buli ni maksudnya perbuatan mengasari orang } \\ \text { yang lemah dengan tujuan untuk menunjukkan } \\ \text { kekuatan masing-masing. Ada tak dalam kelas ni } \\ \text { yang buat perangai macam ni? }\end{array} \\ & \text { Tak de (Pelajar menjawab beramai-ramai) } \\ \text { Pelajar: } & \begin{array}{l}\text { Tak de kan. Tahu, anak-anak murid cikgu semuan- } \\ \text { Guru: }\end{array}\end{array}$

\section{Substrategi KP8}

Ekstrak 10

Konteks:

Guru menggunakan elemen gurauan apabila guru meminta pelajar daripada kumpulan tertentu membentangkan hasil perbincangan.

$\begin{array}{ll}\text { Guru: } & \text { Dah bersedia, kumpulan pertama? } \\ \text { Pelajar: } & \text { Malu cikgu. } \\ \text { Guru: } & \begin{array}{l}\text { Tak payah malu-malu. Jangan hari ni pulak } \\ \text { kamu nak malu. (nada bergurau bukan nada } \\ \text { marah). }\end{array}\end{array}$




\section{6. $\quad$ Substrategi KP9}

Ekstrak 11

Konteks:

Guru mengambil kira keinginan dan keperluan pelajar tentang kesesuaian tempoh masa yang ditetapkan untuk menyelesaikan tugasan yang diberikan.

$\begin{array}{ll}\text { Guru: } & \text { Baiklah, masa hampir tamat. Ada mana-mana kum- } \\ & \begin{array}{l}\text { pulan yang dah siap? Boleh tampal di stesen yang } \\ \text { cikgu dah sediakan di hadapan kelas. }\end{array} \\ \text { Pelajar: } & \begin{array}{l}\text { Belum (Sebahagian pelajar menjawab beramai-ra- } \\ \text { mai) }\end{array}\end{array}$

Baik, cikgu bagi masa sikit lagi untuk kamu siapkan.

\section{Substrategi KP9}

\section{Ekstrak 12}

Konteks:

Guru menawarkanjanjikepada pelajarberkaitan aktiviti pembelajaran yang hendak dijalankan.

Guru:

Baiklah sekejap lagi cikgu akan tayangkan kamu satu video. Cikgu nak kamu fokus video tu dan cuba berfikir, apa yang cikgu nak ajar kamu hari ini?

\section{Substrategi KP11}

\section{Ekstrak 13}

Konteks:

Guru menonjolkan sikap optimistik terhadap pelajarnya yang kelihatan memahami isu yang sedang dikupas oleh guru.

Guru: rang ni pasal apa Arif? 


\section{9. $\quad$ Substrategi KP12}

Ekstrak 14

Konteks:

Guru melibatkan pelajarnya dalam aktiviti dengan mempersilakan pelajarnya untuk membentang hasil kerja kumpulan.

Guru: Okey, kita persilakan Fatihah dengan Alis untuk membentang.

\section{Substrategi KP13}

\section{Ekstrak 15}

Konteks:

Guru memberikan alasan dan justifikasi ciri pemenang tempat pertama dipilih apabila guru menaksir aktiviti pembentangan pelajar.

Guru:

Baik, cikgu sudah buat penilaian hasil tugasan kumpulan kamu. Kumpulan yang pertama dimenangi oleh Kumpulan Wahida. Kumpulan Wahida dijemput. Dia menang sebab siapkan tugasan dengan cepat.

\section{Substrategi KP14}

\section{Ekstrak 16}

\section{Konteks:}

Guru mewujudkan hubungan timbal balik dengan memberikan pelajarnya mendengar lagu, kemudian pelajar pula perlu mengemukakan kata ganda yang terdapat dalam liriknya.

\begin{tabular}{|c|c|}
\hline Guru: & $\begin{array}{l}\text { Lepas lagu tu habis dimainkan, cikgu akan tanya siapa- } \\
\text { siapa saja secara rawak. Cikgu akan panggil nama supa- } \\
\text { ya kamu bagitahu apa contoh kata ganda yang terdapat } \\
\text { dalam lirik. Boleh? Boleh faham? }\end{array}$ \\
\hline Pelajar: & Boleh. (Pelajar menjawab beramai-ramai) \\
\hline
\end{tabular}

\section{Substrategi KP15}

Ekstrak 17

Konteks:

Guru memberikan ganjaran bukan fizikal dalam bentuk pujian kepada pelajarnya yang berjaya menjawab soalan yang diajukan. 


$\begin{array}{ll}\text { Guru: } & \begin{array}{l}\text { Aidil, sila berikan contoh salah satu kata ganda yang } \\ \text { terdapat dalam lirik lagu. }\end{array} \\ & \text { Pagi-pagi } \\ \text { Pelajar: } & \begin{array}{l}\text { Haaa... Yang ini baru betul.(Guru memberi respons } \\ \text { dengan nada gembira dan wajah yang ceria) }\end{array} \\ \text { Guru: } & \end{array}$

\section{Fasa Penutup Pengajaran}

Berdasarkan kajian, didapati bahawa terdapat lima Substrategi Kesantunan Positif yang digunakan oleh guru pelatih dalam sesi penutup pengajaran. Substrategi tersebut merangkumi substrategi menggunakan elemen gurauan (KP8), mengambil kira keinginan pendengar (KP9), menawar atau memberi janji (KP10), mengandai atau menyatakan hubungan timbal balik (KP14) dan memberi penghargaan (KP15). Contoh ujaran yang mengandungi Strategi Kesantunan Positif melalui substrateginya mengikut konteks dan peristiwa bahasa berdasarkan data kajian adalah seperti yang berikut:

\section{Substrategi KP8}

Ekstrak 18

Konteks:

Guru menggunakan elemen gurauan apabila menutup pengajaran apabila mendapati pelajarnya seperti ingin meneruskan aktiviti PdPc berasaskan gamifikasi yang menarik.

Guru:

Kita akan buat lagi permainan ni di kelas akan datang. Esok kita akan jumpa lagi kan? Kumpulan Sheika jangan sedih sangat. Nanti cikgu pun sedih (dengan nada gurauan). Terima kasih kelas.

\section{Substrategi KP9}

Ekstrak 19

Konteks:

Guru mengambil kira keinginan pelajar tentang minat mereka terhadap pembelajaran berasaskan gamifikasi.

Guru:

Terima kasih kelas. Jangan kecewa. Jangan kecewa. Kita akan buat permainan ni di kelas akan datang. 


\section{3. $\quad$ Substrategi KP10}

Ekstrak 20

Konteks:

Guru menawarkan janji kepada pelajar untuk bertemu lagi dalam kelas keesokan harinya.

Guru:

Itu sahaja rumusan pada hari ini. Terima kasih semua. Jumpa lagi pada hari esok.

\section{Substrategi KP14}

Ekstrak 21

Konteks:

Guru mewujudkan hubungan timbal balik dengan menyambut ucapan penghargaan daripada pelajarnya dalam fasa penutup PdPc.

$\begin{array}{ll}\text { Pelajar: } & \begin{array}{l}\text { Terima kasih cikgu (Pelajar mengucapkan secara } \\ \text { beramai-ramai setelah tamat } \mathrm{PdPc}) .\end{array} \\ \text { Guru: } & \text { Sama-sama, duduk }\end{array}$

\section{Substrategi KP15}

Ekstrak 22

Konteks:

Guru memberikan ucapan penghargaan kepada pelajar dalam sesi penutup pengajaran.

\section{Guru: \\ Baik, terima kasih untuk semua kerjasama awak hari ini. Awak nak ke kelas Matematik ya? Baiklah, terima kasih semua.}

Berdasarkan data yang diperoleh, didapati bahawa semua Strategi Kesantunan Positif hadir dalam korpus data ini. Ini menunjukkan bahawa, guru pelatih peka dengan amalan kesantunan berbahasa dalam melaksanakan pengajaran, pembelajaran dan pemudahcaraan. Dalam kajian ini, aspek sosiopragmatiknya diteliti menerusi pemberatan lakuan ancaman muka (LAM) yang dipengaruhi oleh faktor jarak sosial dan perbezaan kuasa antara penutur dan pendengar. Dalam konteks kajian ini, penutur merujuk kepada guru, manakala pendengar pula merujuk kepada pelajar. Selain faktor jarak sosial dan perbezaan kuasa, darjah imposisi sesuatu lakuan komunikatif 
yang digunakan juga boleh menjadi faktor kepada pemberatan sesuatu lakuan ancaman muka. Walaupun jarak sosial dan perbezaan kuasa jelas wujud antara guru pelatih dan pelajar, namun dalam komunikasi dalam PdPc tersebut menunjukkan Strategi Kesantunan Positif tetap diamalkan.

Jelasnya, didapati bahawa guru menggunakan Strategi Kesantunan Positif dalam ujaran mereka ketika berinteraksi dengan pelajar dalam kelas walaupun darjah imposisi yang terhasil semasa mengujarkan sesuatu lakuan komunikatif itu tidak memberi kesan bebanan yang besar kepada murid. Hal ini demikian, kerana pelajar seharusnya akur dengan arahan atau permintaan guru dan tidak pula menjadi satu bebanan yang besar kepada pelajar apabila mereka mengikuti arahan guru dalam proses PdPc. Sungguhpun kesan bebanan tidak ketara apabila guru melaksanakan lakuan ancaman muka seperti lakuan memberi arahan misalnya, didapati bahawa guru masih memilih untuk menggunakan Strategi Kesantunan Positif semasa berinteraksi dengan pelajar.

\section{Upaya Berbahasa Sebagai Indikator Profesionalisme Guru Pelatih dalam Konteks Pembangunan Pendidikan Kebangsaan}

Jelasnya, kajian ini menyumbang kepada negara, iaitu mendukung konsep pembinaan negara yang bersepadu dan holistik dengan mengambil tanggungjawab khususnya untuk memiliki bahasa negara, iaitu Bahasa Melayu Tinggi dan Berbudaya (BMTB) yang dapat menjadi teras jati diri rakyat yang merdeka dan bermaruah serta memiliki bahasa yang dapat menjadi jambatan menyatupadukan rakyat pelbagai keturunan khususnya dalam urusan pendidikan negara, iaitu pendidikan Bahasa Melayu melalui PdPc di sekolah.

Guru yang menjadi aset penting dalam merealisasikan hasrat ini mestilah terus berupaya dalam meneruskan usaha ke arah mempraktikkan amalan berbahasa Melayu tinggi dan berbudaya. Hal ini demikian kerana guru yang mempunyai kemampuan berfikir dalam bahasa yang baik (BMTB) akan melahirkan konsep yang baik dalam mengajarkan ilmu tentang bahasa, budaya dan pemikiran Melayu (Bahari \& Mohamed Redzwan, 2013). Ini jelas menunjukkan bahawa kemampuan berbahasa khususnya dari sudut morfofonetik, sosiolinguistik dan sosiopragmatik sangat penting bagi meningkatkan potensi kefahaman murid dalam isi kandungan 
matapelajaran yang diajarkan oleh guru dan dalam masa yang sama dapat meningkatkan profesionalisme sebagai bakal pendidik khususnya dalam mata pelajaran bahasa Melayu.

Elemen kesantunan merupakan aspek yang dapat memberi manfaat dalam situasi pengajaran dan pembelajaran (Kerssen-Griep, Hess, \& Trees, 2003; Wang et al., 2008). Dalam usaha memartabatkan bahasa menerusi peranti bahasa santun, wahana ini sering dikaitkan dengan pendekatan berbahasa dan berbudaya tinggi. Hal ini disokong daripada kajian-kajian terkini yang menyokong kepentingan elemen pengamalan budaya dan impaknya dalam bidang pendidikan. Brown, Chen, Davies, Garcia \& Godinez (2019) dalam kajiannya telah meneliti sifat dan kepentingan nilai pendidikan di China, England, MexicodanSepanyol,yangmengamalkanpendidikanmultikulbudaya dan bagaimana mereka melaksanakannya dalam pembangunan profesion guru sekolah sebagai komponen dalam pendidikan dan perkhidmatan. Kajian oleh Miled (2019) pula memperkukuhkan kepentingan pendekatan budaya dalam menggerakkan organisasi supaya bersifat transformatif. Seterusnya, kajian oleh Johansen \& Tkachenko (2019) pula menunjukkan bagaimana amalan akademik dan norma-norma bilik darjah perlu mendominasikan pembelajaran berbudaya bagi membentuk budaya baharu dan dapat meneruskan kesinambungan proses ilmu dengan melihat peranan timbal balik guru-murid dalam konteks pembelajaran yang bersinergi dengan elemen budaya tinggi.

Jelasnya, guru pelatih seharusnya berupaya menunjukkan kredibiliti dan potensi serta kompetensi BMTB yang tinggi khususnya dalam aspek kesantunan berbahasa dalam kalangan guru pelatih. Dalam menyentuh aspek profesionalisme, pendidik khususnya guru pelatih disarankan bersikap eklektik demi meningkatkan profesionalisme pendidik dari segi akademik berkaitan ilmu linguistik mahupun akhlak merujuk amalan santun berbahasa dengan memadukan setiap sudut positif dalam aliran linguistik dengan melaksanakan pendidikan bahasa secara berkesan.

Sebagai kesinambungannya, dalam memartabatkan bahasa, pengguna bahasa wajarlah menggunakan BMTB dalam interaksi dan komunikasi dalam konteks formal (Mohamed Redzwan, 2013). Dalam kajian ini, konteks formal merujuk kepada Pengajaran dan Pemudahcaraan $(\mathrm{PdPc})$ dalam kelas yang melibatkan komunikasi 
guru pelatih-pelajar. Bentuk komunikasi ini menyerlahkan wacana pengajaran yang sebenar. Menurut Omar (2002) martabat bahasa Melayu terletak pada bentuk wacana yang digunakan. Ciri wacana yang berdaya tinggi terdapat pada pengungkapan fikiran dan penggunaan bahasa yang akan membuat pendengar yang menjadi sasaran wacana itu menerimanya dengan mudah dan dengan sikap yang positif. Bahasa yang baik dalam wacana yang berdaya tinggi tidak terbatas kepada kepatuhan keperluan nahu, tetapi aspek lain dalam penggunaan bahasa. Aspek-aspek berkenaan adalah aspek sosiolinguistik dan sosiopragmatik. Aspek sosiolinguistik menggambarkan hubungan sosial antara penutur dan pendengar, supaya wujud situasi saling menghormati. Dalam erti kata lain, kesantunan berbahasa merupakan salah satu ciri penting dalam bahasa Melayu tinggi yang tidak seharusnya dikesampingkan (Mohamed Redzwan, 2013). Aspek sosiopragmatik dalam penggunaan bahasa pula memberikan tumpuan kepada tujuan penggunaan bahasa, iaitu kesan yang ingin disampaikan dan tindakan lanjutan kesan daripada sesuatu lakuan tuturan itu. Kedua-dua disiplin ini perlu saling beriringan bagi menyerlahkan wahana kesantunan yang sebaik-baiknya. Dengan demikian, ada peraturan sosiolinguistik yang perlu dipatuhi. Jelasnya, penggunaan bahasa yang tidak halus dari segi sosiolinguistik tidak membawa kesan yang positif dari segi pragmatik kerana komunikasi yang sebegini tidak berdaya tinggi, sungguhpun bahasa yang digunakan betul dari segi nahu.

Selain itu, peranan BMTB dikaitkan juga dari sudut ketamadunan dan budaya tinggi. Menurut Tan Sri Dr. Rais Yatim dalam ucaptama bertajuk Pencapaian Budaya Tinggi di Kalangan Masyarakat Malaysia di Pusat Pengajian Luar Universiti Beijing (BFSU), China pada 11 Mei 2017 menyatakan bahawa rahsia ketamadunan adalah melalui penerokaan dunia dengan bahasa yang kecenderungannya terus menjadi bahasa pembudayaan serta lain-lain fungsi yang terisi melalui hiburan, komunikasi, penulisan, politik. Menurut beliau lagi, realitinya, bahasa memainkan peranan penting dalam pembudayaan, apatah lagi dalam budaya tinggi. Beliau berani menyatakan bahawa jika dasar menjadikan bahasa Melayu sebagai bahasa ilmu dan bahasa perdagangan tidak dilaksanakan, lambat laun bahasa Melayu akan menghilang dari arus perdana. Ini menunjukkan bahawa bahasa Melayu yang perlu dimartabatkan lagi penggunaannya seharusnya BMTB kerana BMTB merupakan bahasa budaya tinggi dan dalam masa yang sama merupakan bahasa yang berbudaya. 
Seterusnya, peranan bahasa sebagai bahasa ilmu dalam budaya tinggi jelas ditonjolkan sejak dahulu lagi melalui Falsafah Pendidikan Bahasa Melayu yang dirancang sejajar dengan Falsafah Pendidikan Kebangsaan yang antara lainnya bertujuan mengembangkan potensi berbahasa dalam kalangan pelajar, di samping menjadi wahana pewarisan nilai-nilai kehidupan bermasyarakat dan juga menjadi satu cabang pendidikan umum (Sariyan, 2014). Apabila dihayati akan idealisme Falsafah Pendidikan Negara yang bercita-cita melahirkan generasi yang bersepadu, iaitu seimbang dan harmonis penguasaan ilmu umum dan ilmu khususnya dengan penguasaan bahasa sebagai ilmu asas, seimbang dan harmonis antara penguasaan sistem bahasa dan kemahiran bahasa dengan ilmu dan akhlak menuntut peningkatan profesionalisme para pendidiknya.

Pendidik yang sejati, ideal dan profesional ialah individu yang mengisytiharkan kepatuhan atau ketaatan kepada bidang pendidikan, individu yang telah berikrar dan mengaku mengabdikan dirinya kepada kerjaya pendidikan (Sariyan, 2014). Tambah beliau lagi, beberapa orang yang berwibawa dalam bidang pendidikan seperti Cormin (1965); Havighurst \& Levine (1979); Howson et al. (1976) menegaskan bahawa kerjaya pendidik sebagai bidang yang profesional.

Hakikatnya, guru yang profesional amat diperlukan dalam usaha kita membangunkan pendidikan kebangsaan berkualiti. Bagi mencapai hasrat tersebut, titik permulaan ke arah itu ialah dengan menyediakan guru pelatih dengan memiliki ciri-ciri mengikut standard yang telah digariskan secara berkesan. Antara instrumen yang menjadi panduan dan piawaiannya terkandung dalam aspekaspek penilaian yang perlu dicerap ke atas guru pelatih semasa menjalani latihan mengajar di sekolah. Menurut Mustofa (2007) dalam usaha membangunkan pendidikan nasional, guru (pendidik) dalam standard mutu, kompetensi dan profesionalisme yang terjamin sangat diperlukan. Untuk mencapai jumlah guru profesional yang dapat menjana dinamika kemajuan pendidikan nasional, proses pembinaan berkesinambungan, tepat sasaran dan efektif juga diperlukan. Proses mencapai tahap guru profesional ini perlu didukung oleh semua unsur yang terkait dengan guru. Unsur-unsur tersebut dapat dipadukan bagi menghasilkan suatu sistem yang dapat dengan sendirinya bekerja menuju pembentukan guru-guru yang profesional dengan kualiti dan kuantiti yang mencukupi. Oleh yang 
demikian, usaha berterusan bagi mendorong dan memberdayakan pendidik yang profesional perlu dilaksanakan terus-menerus.

Jelasnya, penggunaan BMTB berlangsung dari permulaan pengajaran sehinggalah penutup dalam fasa perkembangan PdPc. Aspek penggunaan bahasa dalam komunikasi guru pelatih ada disentuh dan menjadi salah satu elemen yang dinilai dalam latihan mengajar. Namun, aspek tersebut disentuh secara umum sahaja dalam buku Panduan Penyeliaan Latihan Mengajar UPSI (Pindaan 2013) dengan andaian pensyarah penyelia, guru pembimbing dan guru pelatih sedia tahu.

Memandangkan kajian ini melibatkan guru-guru pelatih Universiti Pendidikan Sultan Idris, sewajarnya rubrik atau skala panduan untuk penyeliaan latihan mengajar dalam buku Panduan Latihan Mengajar UPSI (Pindaan 2013) yang menyentuh aspek upaya berbahasa guru pelatih dalam item komunikasi atau pertuturan dalam Bahagian B, iaitu Bahagian Perkembangan diperincikan, diteliti semula dan dilaksanakan berteraskan indikator pengukuran yang bersifat tatabahasa dan tatasosial. Deskripsi skala bagi kategori komunikasi yang berhubung kait dengan kajian ini antaranya berasaskan fitur yang berikut:

1. Kejayaan guru pelatih menggerakkan pelajar melalui penggunaan bahasa yang ekspresif dan berkesan (lisan bukan lisan);

2. Kualiti suara, keupayaan mempelbagaikan nada dan intonasi serta kelantangan suara sesuai, sebutan jelas, tepat dan menarik; dapat mengekalkan perhatian murid.

Dalam kajian ini, item berkaitan bahasa yang ekspresif dan berkesan dan item tentang sebutan yang tepat dan jelas dikaji lebih mendalam, iaitu di bawah payung penggunaan BMTB khususnya kesantunan berbahasa yang merangkumi aspek morfofonetik, sosiolinguistik dan sosiopragmatik.

Ciri-ciri profesional juga disentuh atau dinilai dalam bahagian $\mathrm{C}$, iaitu bahagian sikap dan professional dalam buku Garis Panduan Latihan Mengajar UPSI (Pindaan 2013). Deskripsi skala bagi kategori komunikasi, yang berhubung kait dengan kajian ini antaranya berasaskan fitur yang berkaitan dengan keupayaan guru pelatih dalam: 
1. menunjukkan tanggungjawab, iltizam dan dedikasi,

2. menunjukkan pekerti terpuji, jujur, bersifat mulia. Sebagai model kepada murid dan guru lain di sekolah.

Jelasnya, kajian ini juga menyahut ciri profesional yang dihasratkan oleh Universiti Pendidikan Sultan Idris (UPSI). Sedar akan kepentingan ini, upaya berbahasa Melayu tinggi dan berbudaya yang mencerminkan kesantunan berbahasa seharusnya menjadi salah satu indikator profesionalisme guru khususnya guru Bahasa Melayu sehingga mampu menjadi model kepada murid dan guru lain di sekolah yang bukan sahaja cemerlang akademiknya malah cemerlang juga akhlaknya seperti yang dihasratkan oleh UPSI.

\section{KESIMPULAN}

Kesimpulannya, kajian yang dijalankan ini mampu menyumbang informasi berkaitan kelemahan dan kelebihan guru pelatih khususnya dari segi upaya mereka berbahasa Melayu tinggi dan berbudaya yang sewajarnya dititikberatkan dan diberi penekanan secara berterusan berbekalkan semangat setia bahasa dan setia negara. Seterusnya, dengan mengemukakan aspek kesilapan yang berkemungkinan tinggi dilakukan dalam kalangan guru pelatih berasaskan amalan sebenar di tempat kajian boleh dijadikan panduan dan peringatan bagi pelajar yang bakal menjalani latihan mengajar. Di samping memberikan panduan aspek pematuhan berbahasa Melayu tinggi dan berbudaya berdasarkan kesedaran pengkaji terhadap kelemahan yang dapat dikesan, beberapa solusi berkaitan aspek masalah kebahasaan khususnya berkaitan upaya berbahasa khususnya BMTB dalam kalangan mereka juga boleh dimanfaatkan. Hal ini demikian kerana, guru pelatih perlu bersedia terutamanya dalam hal berkaitan kompetensi berbahasa sebelum melangkah menjadi guru terlatih dan sewajarnya profesional dalam profesion keguruan.

Jelasnya, guru pelatih seharusnya berupaya menunjukkan kredibiliti dan potensi serta kompetensi BMTB yang tinggi khususnya dalam aspek kesantunan berbahasa dalam kalangan guru pelatih. Dalam menyentuh aspek profesionalisme, pendidik khususnya guru pelatih disarankan bersikap eklektik demi meningkatkan profesionalisme pendidik dari segi akademik berkaitan ilmu linguistik mahupun akhlak merujuk amalan santun berbahasa dengan memadukan 
setiap sudut positif dalam aliran linguistik dengan melaksanakan pendidikan bahasa secara berkesan.

\section{PENGHARGAAN}

Penghargaan ditujukan kepada pihak Pusat Pengurusan Penyelidikan dan Inovasi (RMIC), Universiti Pendidikan Sultan Idris atas pengurniaan Geran Galakan Penyelidikan Universiti 2017 (GGPU) bagi melaksanakan penyelidikan ini. Artikel ini merupakan hasil penyelidikan GGPU 2017-0102-106-01 bertajuk Upaya Berbahasa Melayu Tinggi dan Berbudaya (BMTB) dalam Kalangan Guru Pelatih Berasaskan Skala Sosiopragmatik sebagai Indikator Profesionalisme Bakal Pendidik.

\section{RUJUKAN}

Abdul Aziz, S. H. (2010). Pragmatik linguistik. Kuala Lumpur: Penerbit Universiti Malaya.

Aman, I., \& Abd Hamid, S. (2001) Variasi sosial dalam sebutan BM: Kajian sosiofonologi di sekolah. Jurnal Dewan Bahasa, 4(1): 446-466.

Arshad, M. (2012). Bahasa melayu tinggi. Serdang: Penerbit Universiti Putra Malaysia.

Baggini, J. (2005). What professionalism means for teachers today? Education Review, 18(2), 5-11.

Bahari, K. A., \& Mohamed Redzwan, H. F. (2013). Upaya bahasa dan berbahasa dalam mengajarkan ilmu bahasa, budaya dan alam pemikiran Melayu. Dalam J. Dahlia \& R. Sri Lanang Jaya (Pnyt.), Sang Budiman (ms. 423-431). Batu Caves: PTS Akademia.

Boyt,T.,Lusch,R.F.ve Naylor, G.(2001). The role of professionalism in determining job satisfaction in professional services: a study of marketing researchers, Journal of Service Research, 3(4), 321-330.

Brown, E., Chen, D., Davies, I., Garcia, A. U., \& Godinez, I. M. (2019). Educating young people about society in China, England, Mexico and Spain: Similar approaches to values education from different contexts. Compare: A Journal of Comparative and International Education. doi: 10.1080/03057925.2019.1647513 
Brown, P., \& Levinson, P. (1987). Politeness: Some universals in language usage. Cambridge, England: Cambridge University Press.

Chia, Y. P. (2014) Kaedah penyelidikan. (ed. ke-3). Shah Alam: Mc Graw Hill Education

Chiew,C.M.,MohdHasani Dali.,\&Lim,C.S.(2016).Implementation of lesson study as an innovative professional development model among Malaysian school teachers. Malaysian Journal of Learning and Instruction, 13(1): 83-111.

Cohen, L., Manion, L., \& Morrison, K. (2000). Research methods in education. 5th Edition. London: Routledge Falmer.

Demirkasımoğlu, N. (2010). Defining "Teacher Professionalism" from different perspectives. Procedia Social and Behavioral Sciences, 9, 2047-2051.

Edwards, J. (2013). Sociolinguistics: A very short introduction. Oxford: Oxford University Press.

Fraenkel, J. R., \& Wallen, N. E. (1996). How to design and evaluate research. USA: Mc Fraw-Hill Inc.

Hamzah, A. (2010). Kaedah kualitatif dalam penyelidikan sosiobudaya. Jurnal Pengajian Media Malaysia, 6(1): 1-10.

Hassan, A. (1987). Isu-isu perancangan bahasa: Pengintelektualan Bahasa Malaysia. Kuala Lumpur: Dewan Bahasa dan Pustaka.

Hassan, A. (2007). Linguistik am. Selangor: PTS Professional.

Hassan, A. (2012, April 13). Bahasa Melayu tinggi - Bahasa intelektual. Ucapan Persidangan Kebangsaan Pengurusan Pendidikan Pengetua Sekolah Malaysia ke-51, Zenith Hotel, Kuantan http://pts.com.my/berita/bahasa-melayu-tinggibahasa-intelektual

Hassan. A. (2014). Langkah-langkah memantapkan Bahasa Melayu di Malaysia dan membina jaringan antarabangsa. Dalam M. N. Sanat, A. B. Siti Saniah \& O. Zulkifli (Pnyt.), Jaringan Pengajian Bahasa Melayu (ms. 43-49). Tanjong Malim: Penerbit UPSI.

Hassan, A. (2016). Sukatan BM 2002 (pindaan): Antara penggabungjalinan kemahiran berbahasa dan tatabahasa dengan penyerapan kemahiran bernilai tambah. Dalam P. Ambigapathy, H. Murshidi @Zakaria, Tan, H. T., J. Siti Noraini \& A. Noraini (Pnyt.), Pancadimensi Pengajaran dan Pembelajaran Bahasa: Trend dan Amalan. Pulau Pinang: Penerbit Universiti Sains Malaysia. 
Idris, N. A., Sarudin, A., Md. Idris., \& M. R (2013). Amalan guru dan penguasaan ilmu linguistik dalam kalangan guru Bahasa Melayu di Perak. Jurnal Pendeta, 4, 2013, 116-141.

Idris, N. A., Sarudin, A., \& Md. Idris (2013). Amalan guru dan penguasaan ilmu linguistik dalam kalangan guru Bahasa Melayu di Perak. Jurnal Pendeta, 4, 2013, 116-141.

Johansen, J. S., \& Tkachenko, E. (2019). Exploring the dynamics of cultures of learning in internationalised higher education. Teaching in Higher Education. 24(5), 633648. doi: 10.1080/13562517.2019.1619546

Karim, N. S. (1986). Bahasa Melayu tinggi: Teori dan penerapan. Kuala Lumpur: Persatuan Linguistik Malaysia.

Karim, N. S. (2007). Kesantunan bahasa dalam konteks masyarakat Malaysia kini. Kuala Lumpur: Persatuan Linguistik Malaysia.

Kasa, Z., Asimirin, S., Jamian, A. R., \& Othman, Y. (2001). Perpepsi pelatih terhadap latihan mengajar. Suara Pendidik, 23, 2030 .

Kerssen-Griep, J., Hess, J. A., \& Trees, A. R. (2003). Sustaining the desire to learn: Dimensions of perceived instructional facework related to student involvement and motivation to learn. Western Journal of Communication, 67, 357 - 381. doi: 10.1080/10570310309374779[Taylor \& Francis Online], [Google Scholar]

Leech, G. (1983). Principles of pragmatics. London: Longman.

Leech, G. (1993). Prinsip pragmatik. (Azhar M. Simin, Terj.). Kuala Lumpur: Dewan Bahasa dan Pustaka. (Karya asal diterbitkan pada 1983).

Leech, G. (2014). The pragmatics of politeness. Oxford: Oxford University Press.

Lim, K. C., Mahat, N. I., Hassan, S., Chik, A. R., \& Yahua, M. A. (2010). Penilaian terhadap prestasi pelajar dan pengurusan Program Praktikum Universiti Utara Malaysia. Malaysian Journal of Learning and Instruction, 7, 133-164.

Mahmood, A. H. (2002). Guru dan Bahasa Melayu. Kuala Lumpur: Media Printed (M).

Mahmood, A. H. (2012). Memartabatkan Bahasa Melayu sebagai bahasa ilmu. Dalam A. H. Mahmood, A. B. Siti Saniah \& M. N. Sanat (Pnyt.), Memartabatkan Bahasa Melayu pengajian bahasa (ms. 14-33). Tanjong Malim: Penerbit UPSI.

Mahmood, A. H. (2013). Memartabatkan Bahasa Melayu sebagai bahasa ilmu di universiti dan IPT. Dalam J. Dahlia \& R. Sri 
Lanang Jaya (Pnyt.), Sang Budiman (ms. 389-406). Batu Caves: PTS Akademia.

Marican, S. (2005). Kaedah penyelidikan sains sosial. Petaling Jaya: Pearson Prentice Hall.

Meriam, S. B. (2001). Qualitative research and case study applications in education (Second Edition). San Francisco: Josey-Bass.

Miled, N. (2019). Educational leaders' perceptions of multicultural education in teachers' professional development: A case study from a Canadian school district. Multicultural Education Review. 11(2), 79-95. doi: 10.1080/2005615X.2019.1615249

Mohamed Redzwan, H. F. (2013). Partikel wacana dan kesantunan bahasa. Dalam M. N. Sanat, M. R. Idris, K. A. Bahari \& S. Anida (Pnyt.), Penyelidikan Bahasa Melayu. Tanjong Malim: Penerbit Universiti Pendidikan Sultan Idris.

Mohamed Redzwan, H. F., Sarudin, A., \& Bahari, K. A. (2018). Upaya Berbahasa Melayu tinggi dan berbudaya (BMTB) dari sudut morfo-fonetik dan sosiolinguistik dalam kalangan guru pelatih. Journal of Humanities, Language, Culture \& Business Journal, 2(8): 153-161.

Mohamed Redzwan, H. F., Sarudin, A., Ramli, Z., \& Bahari, K. A. (2018c). Kesantunan berbahasa indikator profesionalisme guru pelatih. Dalam Proceeding $2^{\text {nd }}$ International Conference on Social Sciences, Humanities and Technology (ms. 394402). Kota Bharu: Global Academic Excellence.

Mohd Zubir, S. K. (2012). Kecemerlangan guru Bahasa Melayu dalam memartabatkan Bahasa Melayu. Dalam A. Mahzan, M. R. Idris \& M. Naffi (Pnyt.), Memartabatkan Bahasa Melayu pengajaran dan pembelajaran (ms. 21-38). Tanjong Malim: Penerbit Universiti Pendidikan Sultan Idris.

Mustofa. (2007). Upaya pengembangan profesionalisme guru di Indonesia. Jurnal Ekonomi \& Pendidikan, 4(1), 76-88.

Neuman, W. L. (2006). Social research method: Qualitative and quantitative approaches. Toronto: Pearson.

Nordin,M.Z.,Ariffin, M.T.,Jamaluddin, N., Bahari,K.A., Mohamed Redzwan, H. F., \& Yusof, A. (2014). Memartabatkan Bahasa Melayu di sekolah: Pengetahuan, sikap dan amalan guru-guru terhadap Bahasa Melayu Tinggi. Dalam O, Zulkifli, M. N. Sanat \& J. Dahlia (Pnyt.), Jaringan Pedagogi Bahasa Melayu (ms.103-120). Tanjong Malim: Penerbit UPSI.

Omar, A. (1982). Language and society in Malaysia. Kuala Lumpur: Dewan Bahasa dan Pustaka. 
Omar, A. (2002). Setia dan santun Bahasa Melayu. Kuala Lumpur: Dewan Bahasa dan Pustaka.

Omar, A. (2007, 18-19 Julai). Taksonomi pertemuan bahasa: Di manakah letaknya bahasa rojak? Kertas kerja dibentangkan di Seminar Bahasa Rojak: Kecelaruan Penggunaan Bahasa Melayu, anjuran Dewan Bahasa dan Pustaka dan Persatuan Bahasa Moden Malaysia, Kuala Lumpur.

Omar, A. (2011). Kajian dan perkembangan Bahasa Melayu. Kuala Lumpur: Dewan Bahasa dan Pustaka.

Osman, Z., Sarudin, A. Janan, D., \& Omar, A. (2019). The teaching of Malay essay writing based on an authentic Approach. International Journal of Innovative Technology and Exploring Engineering (IJITEE). 8(7S2), 175-181.

Osman, Z., Sarudin, A., Abdul, A. H., \& Ayob, R. (2019). Teachers' Understanding and the Level of Implementation of Authentic Elements in the Teaching of Malay Language Writing and Their Relationships with School Type, Teachers' Experience, and Specialization. International Journal Academic Research Business and Social Sciences, 9(1), 1245-1256.

Pusat Latihan Mengajar dan Industri Universiti Pendidikan Sultan Idris. (2013). Garis panduan latihan mengajar UPSI (Pindaan 2013). Tanjong Malim: PULAMI.

Raths, J. (2001). Teachers beliefs and teaching beliefs. Early Childhood Research and Practice, 3(1), 1-10.

Riffe, D., \& Freitag, A. (1997). A content analysis of content analyses:

Twentyfive years of Journalism Quarterly. Journalism and Mass Communication Quarterly, 73, 635-644.

Sariyan, A. (2011). Pembudayaan bahasa dan pembentukan rupa bangsa. Dalam S. Arba'ie, A. A. Adi Yasran, B. Ahmad Yusof \& Z. H. Zaitul Azma (Pnyt.), Linguistik dan Pembudayaan bahasa Melayu (ms. 3-59). Kuala Lumpur: Dewan Bahasa dan Pustaka.

Sariyan, A. (2014). Teras pendidikan Bahasa Melayu edisi kedua. Dalam H. Abdullah (Pnyt.). Batu Caves: PTS Akademia.

Sarudin,A., Mohamed Redzwan, H. F., Ayob,A., \& Ramli,Z. (2018). pengamalan kemahiran berfikir aras tinggi (KBAT) dalam pedagogi Bahasa Melayu berdasarkan pengukuran CORT (Cognitive Research Trust). Journal of Global Business and Social Entrepreneurship, 4(11), 134-150.

Sarudin, A., Mohamed Redzwan, H. F., Osman, Z., Raja Ma'amor Shah, R.N.F., \& Mohd Ariff Albakri,I.S. (2019). Menangani 
kekaburan kemahiran prosedur dan terminologi awal Matematik: Pendekatan leksis berdasarkan Teori Prosodi Semantik. Malaysian Journal of Learning and Instruction, 16(2), 255-294.

Sarudin, A., Mohamed Redzwan, H. F, Osman, Z., \& Mohd Ariff AlBakry, I. S. (2019). Using the Cognitive Research Trust scale to assess the implementation of the elements of higher-order thinking skills in Malay Language teaching and learning. International Journal of Recent Technology and Engineering (IJRTE,), 8(2S2), 392-398.

Shaw, K. E. (1978). Understanding the curriculum: The approach through case studies. Journal of Curriculum Studies, 10(1), $1-17$.

Thomas, J. (2013). Meaning in interaction: An introduction to pragmatics. New York: Routledge.

Wang, N., Johnson, W. L., Mayer, R. E., Rizzo, P., Shaw, E., \& Collins, H. (2008). The politeness effect: Pedagogical agents and learning outcomes. International Journal of Human-Computer Studies, 66, 98 - 112. doi: 10.1016/j. ijhcs.2007.09.003

Yale, L., \& Gilly, M. C. (1998). Trends in advertising research: A look at the content of marketing-oriented journals from 19761985. Journal of Advertising. 17(1), 12-22.

Yatim, R. (2017). Pencapaian budaya tinggi di kalangan masyarakat Malaysia. Bahasa Melayu main peranan penting untuk capai budaya tinggi. Diperoleh daripada https://www.menara.my/ bahasa-melayu main-peranan-penting-untuk-capai-budayatinggi/

Yusuff, E., Sarudin, A., \& Jamaluddin, N. (2017). Pendekatan Semantik Ranah dalam analisis makna leksis bahasa sukuan "Lansaran" dalam korpus Bahasa Melayu. Jurnal Pertanika MAHAWANGSA, 4(1), 167 - 186.

Zembal-Saul, C., Blumenfeld, P., \& Krajcik, J. (2000). Influence of guided cycles of planning, teaching, and reflection on prospective elementary teachers' science content representations. Journal of Research in Science Teaching, 37(4), 318-339. 